\title{
Expansion of photic-zone euxinia during the Permian-Triassic biotic crisis and its causes: Microbial biomarker records
}

Wenfeng Zhou ${ }^{\mathrm{a}, \mathrm{b}}$, Thomas J. Algeo ${ }^{\mathrm{a}, \mathrm{c}, \mathrm{d}}$, Xiaoyan Ruan ${ }^{\mathrm{d}}$, Genming Luo ${ }^{\mathrm{a}, \mathrm{b}}$, Zhong-Qiang

Chen $^{\mathrm{a}, \mathrm{b}}$, Shucheng Xie $\mathrm{a}^{\mathrm{a}, \mathrm{b}}$

\begin{abstract}
The incursion of euxinic waters into the ocean-surface layer is hypothesized to have been an important killing agent during the end-Permian mass extinction. However, both the causes and extent of oceanic euxinia during this crisis remain poorly known, making assessment of its role in the mass extinction difficult. Here, we document the distribution of aryl isoprenoids
\end{abstract}


23 (AI), which are biomarkers of obligate anaerobic green sulfur bacteria (Chlorobiaceae) that are indicative of photic-zone euxinia, in 12 Permian-Triassic Boundary (PTB) sections with a wide distribution globally. Profiles of AI abundance for the 12 study sections show significant spatio-temporal variation. No AIs were identified in the shallowest sections, but AIs are present both prior to and following the mass extinction in intermediate-depth sections and following the mass extinction in deep-water sections. This pattern suggests a combination of upward and oceanward expansion of photic-zone euxinia during the PTB crisis, possibly fueled by elevated riverine nutrient fluxes as a consequence of climatic warming, terrestrial ecosystem destruction, and enhanced erosion. This hypothesis is supported by the close association of AIs with elevated abundances of moretanes and dibenzofuran (DBF), which are biomarkers for terrestrial erosion. Expansion of oceanic euxinia at intermediate water depths may have established a long-term reservoir that fed episodic incursions of $\mathrm{H}_{2} \mathrm{~S}$-bearing waters into shallow-marine environments, delaying the recovery of marine ecosystems during the Early Triassic. The biomarker records of the present study thus provide significant evidence of terrestrial-marine linkage during the PTB crisis.

\section{Introduction}

Phanerozoic, killing over $90 \%$ of marine invertebrate species (Erwin et al., 2002). The eruption of the Siberian Traps Large Igneous Province is widely regarded as the ultimate 
Svensen et al., 2009; Korte et al., 2010), but the direct killing mechanism remains controversial, with hypotheses invoking marine anoxia (Wignall and Twitchett, 1996; Isozaki, 1997), hypercapnia (Knoll et al., 2007), global cooling (Joachimski et al., 2012; Romano et al., 2013), and ocean acidification (Hinojosa et al., 2012; Clarkson et al., 2015), among other possibilities. Although early claims of whole-ocean anoxia (e.g., Wignall and Twitchett, 1996; Isozaki, 1997) have been disproven (e.g., Algeo et al., 2011a), more recent studies have shown that the Permian-Triassic boundary (PTB) interval was widely associated with a shift toward more reducing marine environmental conditions (Grice et al., 2005a; Kump et al., 2005; Kaiho et al., 2006; Hays et al., 2007; Riccardi et al., 2007; Gorjan et al., 2007; Algeo et al., 2007, 2008; Meyer and Kump, 2008; Takahashi et al., 2014). However, spatial patterns of marine redox variation (i.e., related to proximality and water depths) have been addressed to only a limited degree in a few studies (e.g., Feng and Algeo, 2014).

Among the various types of geochemical proxies used in paleoredox studies, biomarkers are important for their ability to discern photic-zone euxinia (PZE), i.e., sulfidic conditions within the surface layer of the ocean (Grice et al., 2005a; Xie et al., 2005, 2007; Chen et al., 2015). Certain photosynthetic microbes are obligate anaerobes, requiring both sunlight and $\mathrm{H}_{2} \mathrm{~S}$, e.g., green sulfur bacteria (GSB) and purple sulfur bacteria (PSB) (Whiteside and Grice, 2016). GSB produce isorenieratane and chlorobactane, as well as aryl isoprenoids (AI) as diagenetic breakdown products, and PSB produce okenane, all of which are characteristic indicators of PZE (Summons and Powell, 1986, 1987; Grice et al., 1996; Whiteside and Grice, 2016).

GSB biomarkers have been reported from a number of PTB sections (e.g., Grice et al., 

that at least portions of the global ocean were euxinic during the end-Permian crisis. However, the spatio-temporal distribution of GSB biomarkers in PTB sections has not been investigated in detail, leaving the relationship between oceanic euxinia and the end-Permian mass extinction unclear. Here, we present biomolecular records from multiple locales representing a range of water depths in order to investigate the spatial and temporal distribution of PZE during the end-Permian crisis. Additionally, we examine the relationship of PZE to changes in terrestrial weathering fluxes and tropical sea-surface temperatures (SSTs) in order to gain insights regarding the factors controlling the development of PZE during this crisis. The present study includes new biomarker data for five PTB sections (Bulla in northern Italy, and the Panthalassa, Paleo-Tethys, and Neo-Tethys oceans (Table 1; Fig. 1C). These sections can be catalogued into three types according to sedimentary water depths: (1) shallow platform sections above fair-weather wave base (i.e., water depths $<50 \mathrm{~m}$, and commonly <20 m; cf. Brett et al., 1993), including Bulla in northern Italy and Laolongdong and Cili in South China, (2) intermediate shelf/ramp sections located between fair-weather wave base and storm wave 

Blind Fiord in Canada (Algeo et al., 2012), and (3) deep shelf/ramp sections (>200 m water depth), including Shangsi and Chaohu in South China (Fig. 1C). Background details for each section are given below.

\subsection{Shallow platform sections}

97

The Bulla section (Southern Alps, northern Italy) was located in the western

Paleo-Tethys during the Permian-Triassic transition (Fig. 1). PTB strata belong to the uppermost Bellerophon Formation (Bulla Member) and lower Werfen Formation (Tesero Member). The former consists of gray and dark-gray fossiliferous limestone and dolostone interbedded with siltstone, sandstone and gypsum, whereas the latter comprises oolitic declines in fossil abundance and biodiversity and the appearance of small ooids, is located at pointing to high-energy storm sedimentation in an area proximal to sources of terrigenous clastics. The PTB is located $1.30 \mathrm{~m}$ above the base of the Tesero Member based on the first occurrence of the conodont Hindeodus parvus (Perri, 1991). 
112 paleo-western margin of the Yangtze Platform (South China Craton), facing the Paleo-Tethys

113 Ocean (Liao et al., 2010; Fig. 1). The Upper Permian consists of skeletal limestone of the

114 Changxing Formation that is sharply overlain by microbialite, with the contact between these two units corresponding to the EPME horizon (Ezaki et al., 2003; Kershaw et al., 2012). The occurrence of microbialite implies water depths of $\sim 20-40 \mathrm{~m}$, and the absence of terrigenous sediment indicates an open-marine setting far removed from land areas. The conodont $H$. parvus has been recovered from the uppermost part of the microbialite, which is overlain by Lower Triassic laminated mudstone of the Feixianguan Formation (Wignall and Hallam, 1996). the Yangtze Platform (Fig. 1). The PTB succession consists of muddy limestone and skeletal packstone/grainstone below the EPME horizon (Wang et al., 2009; Yang et al., 2011; Luo et al., 2013, 2014) and thrombolitic calcimicrobialite with limited fossil content (mainly microgastropods, microconchids, ostracods, and conodonts) above the EPME horizon (Ezaki et al., 2003; Wang et al., 2009; Yang et al., 2011, 2015a, b). The Cili section was far from contemporaneous landmasses, thus shielding it from terrestrial influences (Luo et al., 2013).

The PTB is located in the upper part of the microbialite (Yang et al., 2011).

\subsection{Intermediate shelf/ramp sections}


Neo-Tethys during the Permian-Triassic transition (Fig. 1). A detailed study of the litho-, bio-, and carbon-isotope stratigraphy as well as palynofacies and biomarkers of the Hovea Member of the Kockatea Shale was published by Thomas et al. (2004). The Hovea Member consists of two units: (1) fossiliferous black mudstone, sandy siltstone, and shelly storm beds of the lower Inertinitic Interval, in which charcoal and wood fragments dominate the organic fraction; and (2) dark brownish-gray, finely laminated mudstone and thin limestone of the upper Sapropelic Interval, in which amorphous marine algal organic matter is dominant. Well-preserved fossils, locally intense bioturbation, and shelly storm beds suggest deposition at water depths of $\sim 20-50 \mathrm{~m}$ (Thomas et al., 2004). The EPME horizon and PTB are located approximately at the contact of the Inertinitic and Sapropelic intervals.

The Spitsbergen section (Lusitaniadalen, Svalbard, Norway) was deposited in an epicontinental shelf sea located in the boreal region during the Permian-Triassic transition (Fig. 1; Nabbefeld et al., 2010b). This Upper Permian section (Fig. 3) is divided into two units: (1) a lower unit consisting of well-bioturbated, fine-medium-grained, greenish glauconite-rich sandstones, and (2) an upper unit composed of laminated, dark gray mudstones, with occasional thin, ripple-laminated sandstone beds (Mørk et al., 1999). Depositional water depths of $\sim 100 \mathrm{~m}$ are inferred based on sedimentologic features, e.g., glauconite, which forms mainly in mid-shelf environments at depths $>50 \mathrm{~m}$ (Chafetz and Reid, 2000), and siltstone and sandstone beds with ripple lamination indicating open-shelf storm influence, typically at depths of $\sim 50-100 \mathrm{~m}$ (cf. Brett et al., 1993). The EPME is located approximately at the contact between the lower and upper units.

The Peace River Basin section (western Alberta, Canada) is an Apexco drillcore that 
represents a site on the northwestern margin of Pangaea (Hays et al., 2007; Fig. 1). The thin uppermost Permian and thicker Lower Triassic strata (Fig. 3) consist of silty, partially bioturbated mudstone, cross-stratified siltstone with low-angle bedsets, and very fine-grained sandstone. These characteristics imply storm influence on a continental shelf above storm wave base (water depths of $\sim 50-100 \mathrm{~m}$ ). The conodonts Clarkina taylorae and H. parvus were found in the upper part of parasequence G1, in association with a large negative carbon isotope excursion, constraining the location of the PTB (Hays et al., 2007).

The Kap Stosch section (east-central Greenland) was deposited at the margin of the Boreal Ocean during the Permian-Triassic transition (Fig. 1; Teichert et al., 1972; Hays et al., 2012). The uppermost Permian to lowermost Triassic succession shows an abrupt transition from dark shale and siltstone to medium grayish-brown arkosic sandstone at the level of the EPME (Teichert et al., 1972; Fig. 3 and 5). The Permian sediments were deposited in an open-shelf setting that shallowed into the earliest Triassic. Average water depths are estimated at $\sim 80-120 \mathrm{~m}$.

The West Blind Fjord section (Ellesmere Island, Arctic Canada) is located on the margin of the Sverdrup Basin (Fig. 1), part of the larger Boreal Ocean region (Algeo et al., 2012). The measured section consists of $24 \mathrm{~m}$ of medium-bedded black to white spiculitic cherts of the Lindström Formation and thinly bedded siliceous shales of the Blind Fiord Formation deposited in a slope setting at water depths of $\sim 100-200 \mathrm{~m}$. The EPME and PTB, are placed at $10.2 \mathrm{~m}$ and $\sim 13 \mathrm{~m}$, respectively, above the Lindström-Blind Fiord formation contact.

The Huangzhishan section (Zhejiang Province, China) was located on the paleo-northwestern margin of the Yangtze Platform of the South China Block (Fig. 1). The 
PTB succession comprises four units: (1) bioclastic limestone of the Changxing Formation, (2) alternating calcareous mudstone and muddy limestone of the Huangzhishan Formation, (3) mudstone and marlstone of the Yinkeng Formation, and (4) alternating calcareous mudstone and argillaceous limestone of the Helongshan Formation (Chen et al., 2009; Kaiho et al., 2012). The succession shows a sharp transition from high-energy, open-platform facies of the uppermost Changxing Formation to low-energy, restricted-marine facies of the lowermost Huangzhishan Formation (Chen et al., 2010). Average water depths are estimated as $\sim 40-80$ m. The EPME horizon is placed at the base of the Huangzhishan Formation, and the PTB at the first appearance of the conodont H. parvus (base of Bed 25) (Chen et al., 2009).

The Meishan section (Zhejiang Province, China), which is the Global Stratotype Section and Point (GSSP) of the PTB, was located on the paleo-northwestern margin of the South China Craton (Yin et al., 2001; Fig. 1). The latest Permian Changxing Formation comprises medium- to thin-bedded bioclastic limestone, representing a proximal carbonate ramp setting (Zhang et al., 1996; He et al., 2005; Song-HJ et al., 2007). The earliest Triassic Yinkeng Formation consists of greenish mudstone interbedded with thin marlstone, representing a deepening-upward succession (Chen et al., 2007, 2015; Tian et al., 2014). With evidence of both shallow- and deep-water faunal assemblages, water depths have been interpreted as ranging from 30 to $100 \mathrm{~m}$ (Yin et al., 2001; He et al., 2005; Chen et al., 2010; Kaiho et al., 2012; Song-HY et al., 2013). The EPME is located at the base of Bed 25 and the PTB in the middle of Bed 27 (Yin et al., 2001). 
The Shangsi section (Sichuan Province, China) was located on the paleo-southwestern margin of the South China Craton (Fig. 1; Wignall et al., 1995; Lai et al., 1996; Nicoll et al., 2002; Jiang et al., 2011). The PTB interval comprises two units: (1) the Dalong Formation, which consists of black siliceous limestone interbedded with siliceous mudstone, and (2) the Feixianguan Formation, which consists mainly of gray carbonaceous mudstone (Li et al., 1986; Fig. 3 and 6). The Shangsi section was deposited in deeper waters of the partially restricted Guangyuan-Liangping Bay at estimated water depths of $200-300$ m (Yin et al., 2014). The EPME coincides with the Dalong-Feixianguan formation contact, and the PTB with the first occurrence of $H$. parvus $\sim 22 \mathrm{~cm}$ above this contact (Jiang et al., 2011). margin of the South China Craton (Fig. 1; Zhao et al., 2007; Tong and Zhao, 2011). It is a composite of three closely spaced sections at West Majiashan (Permian-Triassic boundary beds), West Pingdingshan (basal Griesbachian to Smithian), and South Majiashan (Smithian to Spathian). It consists of dark siliceous mudstone of the Upper Permian Dalong Formation and yellowish-green calcareous mudstone interbedded with mudstone and white claystone of the Lower Triassic Yinkeng Formation. Both litho- and biofacies data suggest that uppermost Permian to lowermost Triassic strata represent a deep ramp setting with water depths up to 217 200-400 m (Chen et al., 2010, 2011). The EPME is placed at the Dalong-Yinkeng formation contact and the PTB $\sim 18 \mathrm{~cm}$ above this contact (Yin et al., 2014). 
Samples for biomarker analysis were collected from five sections: Bulla (northern Italy), and Laolongdong, Cili, Shangsi, and Chaohu (South China) (Fig. 1). Each sample ( 500 g) was trimmed to remove visible veins and weathered surfaces, broken into small pieces $(\sim 1$ $\mathrm{cm}^{3}$ ), washed in ultrapure water three times, oven-dried overnight, and then rinsed with dichloromethane (DCM). Small pieces of each sample were ground to 150 mesh powder that was processed by accelerated solvent extraction using a solvent mixture of 9:1 dichloromethane: methanol and concentrated via rotary evaporation, with activated copper being added to remove elemental sulfur. Extracts were fractionated by activated silica gel chromatography (using silica gel baked at $500{ }^{\circ} \mathrm{C}$ for $6 \mathrm{~h}$ ) and separated into three fractions by sequential elution: a saturated hydrocarbon fraction ( $n$-hexane), an aromatic hydrocarbon fraction (80\% $n$-hexane: $20 \%$ dichloromethane), a polar fraction (50\% dichloromethane: $50 \%$ methanol). All fractions were dried under a nitrogen purge.

Aryl isoprenoids (AI) in the aromatic fraction were analyzed by gas chromatography (GC) and gas chromatography-mass spectrometry (GC-MS). An Agilent 6890 gas chromatograph linked to an Agilent 5973 mass selective detector equipped with an SLB-5MS capillary column $(30 \mathrm{~m} \times 0.25 \mathrm{~mm}$ internal diameter; film thickness $0.25 \mu \mathrm{m})$ was used for AI analysis. Samples were injected while oven temperature was held constant at $70{ }^{\circ} \mathrm{C}$ and the injector programmed to $320{ }^{\circ} \mathrm{C}$. The oven then followed a temperature program of $3{ }^{\circ} \mathrm{C} \mathrm{min}{ }^{-1}$ to a final temperature of $300{ }^{\circ} \mathrm{C}$, which was held constant for $30 \mathrm{~min}$. Helium was used as the carrier gas, the ionization energy of the mass spectrometer was set at $70 \mathrm{eV}$, and the scan 
areas with an internal standard (chrysene-d). Organic compounds were identified on the basis of mass spectra and retention time of well-characterized samples, per standard protocols (e.g., Grice et al., 2005a).

\section{Results}

Although the three shallow platform sections (Bulla, Cili, and Laolongdong) record the

EPME and an accompanying sharp lithologic change from skeletal limestone to

calcimicrobialite or oolitic limestone, none of these sections yields AIs within the

Permian-Triassic transition interval (Fig. 4). At Bulla, high DBF ratios (0.6-0.9) were

detected at the EPME horizon, whereas most samples from lowermost Triassic strata exhibit intermediate DBF ratios (mostly $0.4-0.5)$. The $\mathrm{C}_{30}$ moretane/hopane $\left(\mathrm{C}_{30} \mathrm{M} / \mathrm{C}_{30} \mathrm{HP}\right)$ ratios vary within a narrow range (0.14-0.19). At Cili, DBF ratios show a slight increase below the EPME horizon (to $\sim 0.4-0.5$ ) and then decrease abruptly at the PTB to values of $\sim 0.2$. $\mathrm{C}_{30} \mathrm{M} / \mathrm{C}_{30} \mathrm{HP}$ ratios are less than 0.12 , varying around 0.10 . At Laolongdong, DBF ratios vary within a low, narrow range (mostly $0-0.2$ ), and $\mathrm{C}_{30} \mathrm{M} / \mathrm{C}_{30} \mathrm{HP}$ ratios are less than 0.2 . elevated abundances both prior to and following the EPME (Fig. 5). A short, sharp spike of $\mathrm{C}_{19}$ AIs was observed immediately above the EPME in the Perth Basin. In the same section, the benzo(e)pyrene / $\sum$ (benzo(a)pyrene + benzo(e)pyrene $(\mathrm{BeP} /(\mathrm{BaP}+\mathrm{BeP}))$ ratios decrease sharply at the EPME, reflecting a decline of terrestrial organic matter inputs (Grice et al., 
horizon, and there is a positive relationship among these proxies in the Lower Triassic interval (Nabbefeld et al., 2010a). Similar results for the Peace River Basin were reported by

Hays et al. (2007) and Nabbefeld et al. (2010a): the highest abundances of all proxies are

found around the EPME, and a positive correlation among these proxies is observed in the

Lower Triassic. At Kap Stosch, AI peaks near the base of the section and correlates positively

with DBT below the PTB (Nabbefeld et al., 2010a; Hays et al., 2012). The relatively deep

water West Blind Fjord section yields low AI concentrations $(<0.008 \mu \mathrm{g} / \mathrm{g}$ TOC) that show positive covariation with $\mathrm{C}_{30} \mathrm{M} / \mathrm{C}_{30} \mathrm{HP}$.

China. Huangzhishan exhibits relatively low AI values (mostly $<0.004 \mu \mathrm{g} / \mathrm{g}$ TOC) that peak at the EPME and in the lowermost Triassic (Kaiho et al., 2012; Fig. 5). At Meishan, there is a strong positive relationship between $\mathrm{AI}$ and $\mathrm{C}_{30} \mathrm{M} / \mathrm{C}_{30} \mathrm{HP}$ (Fig. 5), as documented by Cao et al. (2009) and Xie et al. (2007). Two episodes of elevated AI and $\mathrm{C}_{30} \mathrm{M} / \mathrm{C}_{30} \mathrm{HP}$ values can be observed, with the first episode coincident with the EPME horizon and the second occurring within the lowermost Triassic I. isarcica Zone.

The deep shelf/ramp sections (Chaohu and Shangsi) yield abundant AIs following the EPME but only minor quantities (Chaohu) or none at all (Shangsi) prior to the EPME (Fig. 6).

The deep sections thus resemble the intermediate sections in showing evidence for PZE following the mass extinction but differ in lacking evidence for PZE prior to the biocrisis. As for Meishan, the $\mathrm{C}_{30} \mathrm{M} / \mathrm{C}_{30} \mathrm{HP}$ profile at Shangsi shows a first peak at the EPME and a second peak within the I. isarcica Zone. At Chaohu, the DBT/phenanthrene (Phe) and AI profiles show almost synchronous changes in the lowermost Triassic. 

matter inputs (i.e., DBF) within the narrow EPME-PTB interval, but not in stratigraphically lower or higher beds. For example, samples from the EPME-PTB interval at Shangsi show strong positive covariation of $\mathrm{C}_{30} \mathrm{M} / \mathrm{C}_{30} \mathrm{HP}$ with $\mathrm{AI}\left(\mathrm{r}^{2}=0.72\right.$; Fig. 7A). These covariation patterns imply a causal relationship between GSB blooms and terrigenous organic matter inputs to continental shelves during the latest Permian. In Section 5.3, we hypothesize that land-derived nutrient fluxes stimulated marine phytoplankton productivity, triggering the development of PZE in mid-shelf settings and its oceanward expansion into deeper-water areas during the peak of the biocrisis.

To summarize, AI concentrations in continental shelf settings show a significant relationship to depositional water depths. On the South China Craton, AIs increase from shallow to intermediate settings (e.g., from Huangzhishan to Meishan) and then decrease from intermediate to deep settings (e.g., from Meishan to Shangsi and Chaohu; Fig. 8). A similar pattern is observed for the non-Chinese sections: AI concentrations increase from near-zero in the shallow Bulla section to relatively high values in the intermediate to deep PZE among intermediate-depth sections does not show any relationship to paleogeographic factors such as paleolatitude or ocean-basin location (i.e., Panthalassa versus Tethys).

\section{Discussion}


310 Green sulfur bacteria (GSB), which are common within stratified basins, estuaries, lakes,

311 and coastal embayments, are obligate anaerobic bacteria whose metabolism requires both 312 sunlight and $\mathrm{H}_{2} \mathrm{~S}$ (Grice et al., 1996; Grice et al., 2005b; Sinninghe Damsté and Schouten, 313 2006; Overmann, 2008). They synthesize special aromatic carotenoids such as chlorobactene 314 and isorenieratene, along with a range of other pigments including bacteriochlorophyll-c, $-\mathrm{d}$, 315 and -e (Fig. 2) (Overmann and Tuschak, 1997). During diagenesis, these aromatic carotenoids 316 are usually converted to geologically much more stable counterparts, chlorobactane and 317 isorenieratane. Therefore, the presence of these compounds in sediments are convincing evidence for green sulfur bacterial productivity and, thus, photic zone euxinia (Naeher and 319 Grice, 2015; Plet et al., 2016). These biomarkers have been found in a number of PTB sections, including the Perth Basin (Grice et al., 2005a), Kap Stosch (Hays et al., 2012), the Peace River Basin (Hays et al., 2007), and Meishan (Grice et al., 2005a; Cao et al., 2009). During thermal diagenesis, these compounds can be further cleaved into aryl isoprenoids (AIs). As AIs can also be produced through decay of the carotenoid pigment $\beta$-carotene (Koopmans et al., 1996), they are not uniquely diagnostic of GSB in the absence of other evidence. One way to differentiating these two sources of AIs is via their carbon isotopic compositions: GSB are generally enriched in ${ }^{13} \mathrm{C}$ due to the reversed (or reductive) tricarboxylic acid (TCA) cycle used during carbon fixation (Summons and Powell, 1986, 1987). Unfortunately, the low AI concentrations of the study sections prevented acquisition of $\delta^{13} \mathrm{C}$ data. On the other hand, isorenieratane was found in association with AIs--at Shangsi, these compounds covary with $\mathrm{r}^{2}=0.60$ (Fig. 7B)--suggesting that aryl isoprenoids were 
mainly sourced from isorenieratene and, thus, are strongly indicative of a GSB precursor.

\subsection{Expansion of photic-zone euxinia during the Permian-Triassic transition}

4

It is unlikely that differences in AI concentrations among the study sections were caused by variable diagenesis as they all exhibit low to moderate thermal maturity levels according to Rock-Eval data and biomarker maturity parameters, e.g., Bulla (Tmax $\left.<445^{\circ} \mathrm{C}\right)$, Laolongdong $\left(22 \mathrm{~S} /(22 \mathrm{~S}+22 \mathrm{R})\right.$ of $\mathrm{C}_{31}$ homohopanes $\left.=0.56-0.64\right), \mathrm{Cili}(\mathrm{Ts} /(\mathrm{Ts}+\mathrm{Tm}) \approx 0.5)$, Shangsi $\left(T \max \approx 425^{\circ} \mathrm{C}\right)$, and Chaohu $\left(22 \mathrm{~S} /(22 \mathrm{~S}+22 \mathrm{R})\right.$ of $\mathrm{C}_{31}$ homohopanes $\left.=0.56-0.61\right)$. Systematic relationships were also not observed between AI concentrations and TOC, e.g., Bulla exhibits TOC up to $2 \%$ but zero AIs, and both Kap Stosch and Shangsi exhibit high AI concentrations with low TOC (mainly 0.2-0.9\%). Thus, differences in the concentrations of pigment degradation products do not appear to reflect thermal maturity or TOC content.

The spatio-temporal pattern of GSB biomarkers in the study sections (Figs. 4-6) suggests a major expansion of PZE during the PTB transition (Fig. 8). Prior to the EPME, relatively stable euxinia existed in limited areas on some continental shelves, as shown by non-zero AI abundances in the Huangzhishan, Meishan, Peace River Basin, and Kap Stosch sections, all of which were located at intermediate water depths ( 20-200 m; Table 1). At the same time, shallow-water sections such as Bulla and Cili, and deep-water sections such as Shangsi and Chaohu show no evidence of PZE. Following the EPME, shallow-water sections continue to show no evidence of PZE. Rather, these sections exhibit low $\mathrm{S} / \mathrm{C}_{\text {org }}$ ratios, large framboidal pyrite diameters, and low trace-element concentrations in the post-extinction microbialite that 
are indicative of oxic-dysoxic conditions (Liao et al., 2010; Loope et al., 2013; Song-HY et al., 2014). At water depths of $<20 \mathrm{~m}$, it is likely that any hydrogen sulfide that was generated locally or advected from remote sources was rapidly oxidized to sulfate. However, the post-EPME interval is characterized by GSB blooms in the photic zone of both intermediate and deep-water sections, indicating an oceanward expansion of the areas in which PZE existed. Thus, areas of continental shelf or carbonate platform shallower than $\sim 20 \mathrm{~m}$ were probably not subject to sustained euxinic conditions, and intensification of photic-zone euxinia during the PTB crisis was expressed as oceanward expansion of a wedge-shaped mass of sulfide-bearing, oxygen-depleted water (Fig. 8).

Both in continental shelf and carbonate platform settings, the concentration of AIs in intermediate and deep sections rose rapidly following the EPME, generally peaking prior to the PTB (Figs. 5-6). In the Peace River Basin, West Blind Fiord, Shangsi, and Chaohu, a second peak of AI abundance is observed in the Lower Triassic. These peaks may represent a globally correlative event during the earliest Triassic, although this potential event needs further confirmation through identification in additional sections.

\subsection{Enhanced terrestrial erosion as a trigger for expansion of photic-zone euxinia} useful for assessing inputs of terrigenous organic matter to marine systems (e.g., Xie et al., 2007; Nabbefeld et al., 2010a). Fenton et al. (2007) showed that increased DBT and DBF correlated with spikes in the spores and pollen of woody plants, suggesting that lignin from 
woody plants is a source of DBT and DBF. Other studies have linked DBF and its derivatives to dehydrated polysaccharides (Pastorova et al., 1994), which are extremely abundant in leaf litter and soil and, hence, can potentially serve as an indicator of enhanced soil erosion and terrestrial inputs to marine systems (Sephton et al., 2005). The ratio of $\mathrm{DBF} /(\mathrm{DBT}+\mathrm{DBF}+\mathrm{F}$ ) (where F stands for "fluorences") has been used as an indicator of land-derived organic matter, with higher values indicative of enhanced soil erosion (Wang and Visscher, 2007). Other biomarker proxies for terrestrial inputs include (1) the $\mathrm{C}_{30} \mathrm{M} / \mathrm{C}_{30} \mathrm{HP}$ ratio, with higher values indicative of enhanced terrestrial inputs, as in the EPME horizon at Meishan (French et al., 2012; Xie et al., 2007), and (2) the $\mathrm{BeP} /(\mathrm{BaP}+\mathrm{BeP})$ ratio, with lower values indicative of enhanced terrestrial inputs, as in the EPME horizon of the Perth Basin (Grice et al., 2007). Both in mid-shelf (e.g., Spitsbergen, Peace River Basin, Kap Stosch, West Blind Fiord) and inner-shelf settings (e.g., Huangzhishan, Meishan), intermediate-depth sections show a strong positive relationship between land-derived organic matter and GSB blooms (Fig. 5). An important observation is that, prior to the EPME, proxies for terrestrial inputs had already increased slightly in many of these sections (e.g., Huangzhishan, Meishan, and Spitsbergen), indicating that destruction of terrestrial ecosystems and soil erosion preceded the marine biotic crisis (cf. Sephton et al., 2005). Evidence for enhanced terrigenous inputs prior to the marine crisis can also be seen at Schuchert Dal in eastern Greenland (Fenton et al., 2007), where high abundances of DBT, DBF, and BP are found up to $6 \mathrm{~m}$ below the EPME horizon. Even in deep-water settings such as at Shangsi, an increase in $\mathrm{C}_{30} \mathrm{M} / \mathrm{C}_{30} \mathrm{HP}$ below the EPME horizon (Fig. 6) suggests the influence of terrestrial ecosystem collapse on marine systems. In fact, all of the intermediate and deep sections of the present study that exhibit high AIs 
following the EPME are associated with elevated abundances of moretanes, DBF, and DBT, i.e., biomarkers that are diagnostic of terrestrial erosion and soil inputs.

Elevated riverine nutrient fluxes may have been triggered by rapid soil erosion during the end-Permian crisis and subsequently sustained by enhanced terrestrial erosion under high $p \mathrm{CO}_{2}$ conditions in the post-extinction greenhouse climate (Algeo et al., 2011b; Sun et al., 2012). Enhanced terrestrial erosion during the PTB transition has been documented on the basis of biomarker evidence, i.e., DBT, DBF, retene, and moretane concentrations (Sephton et al., 2005; Xie et al., 2007), sediment fluxes (Algeo and Twitchett, 2010), and Sr isotopes (Korte et al., 2003; Sedlacek et al., 2014). High riverine nutrient fluxes would have stimulated marine primary productivity during the latest Permian to earliest Triassic (Algeo et al., 2011b, 2013; Shen et al., 2015; Wei et al., 2015). According to paleoceanographic modeling results, widespread oceanic anoxia and PZE are likely to have developed if riverine phosphate fluxes during the PTB crisis reached $\sim 10 \times$ the modern value (Meyer et al., 2008;

Winguth and Winguth, 2012). We infer that expansion of euxinia at that time was triggered by a pulse of land-derived nutrients to continental shelves, as suggested by positive covariation of $\mathrm{C}_{30} \mathrm{M} / \mathrm{C}_{30} \mathrm{HP}$ with $\mathrm{AI}$ concentrations (Fig. 7).

\subsection{Global warming as a trigger for expansion of photic-zone euxinia} terrestrial weathering inputs and increased frequency of GSB blooms, there are some 
419 Perth Basin, despite large terrestrial inputs including abundant wood and charcoal (Thomas et 420 al., 2004), suggest that there were other factors influencing GSB activity other than increased 421 nutrient inputs. An abrupt rise of tropical seawater temperatures during the EPME crisis, as 422 documented by conodont apatite oxygen isotope compositions (Joachimski et al., 2012; Sun 423 et al., 2012), may have been the immediate cause of expansion of PZE, as inferred also for 424 the end-Triassic mass extinction (Jaraula et al., 2013). The links between global warming and 425 expansion of PZE include decreased solubility of oxygen in warmer ocean-surface waters 426 (Kennett and Stott, 1991; Kaiho, 1994) as well as an enhanced hydrologic cycle and terrestrial weathering rates (Meyer and Kump, 2008; Algeo et al., 2011b). During the latest Permian in the Perth Basin, global climatic warming led to more humid conditions in the southern subtropics, as shown by pollen and spore records (Hermann et al., 2012). As a consequence, increased riverine discharge into the Perth Basin would have intensified water-column stratification and, thus, stimulated GSB blooms during the end-Permian crisis. These considerations reflect the dominant role that global warming played in the aftermath of the EPME, although its specific effects depended on local paleogeographic and -oceanographic factors. Moreover, with regard to the transition from terrestrial-dominated to algal-dominated organic matter during the EPME crisis proposed by Grice et al. (2007), high marine primary productivity caused by increased land-derived nutrient inputs may have been an important factor. 

the end-Permian biocrisis (Wignall and Twitchett, 1996; Isozaki, 1997; Kato et al., 2002; evidence for PZE in shallow-marine sections of this study, other geochemical proxies have been used to infer the development of at least transient euxinia in some shallow-water PTB sections. At Bulla in northern Italy, small pyrite framboids in oolitic grainstone of the Tesero Member suggest that euxinic conditions existed at the time of the EPME (Bond and Wignall, 2010). At Nhi Tao in northern Vietnam, framboidal pyrite layers appear exactly at the level of the EPME horizon and continue several meters upsection, suggesting a series of brief but possibly intense incursions of $\mathrm{H}_{2} \mathrm{~S}$ onto this shallow carbonate platform (Algeo et al., 2007, 2008). Such short-term incursions of sulfidic waters into the ocean surface layer would have been possible if a long-term reservoir of $\mathrm{H}_{2} \mathrm{~S}$-rich waters existed at intermediate water depths (Feng and Algeo, 2014; this study). The absence of biomarker evidence for PZE in the shallow-water sections of the present study may reflect the briefness of such sulfidic incursions into the ocean-surface layer, after which $\mathrm{H}_{2} \mathrm{~S}$ would have been rapidly oxidized to sulfate and may not have persisted long enough to have allowed an obligate anaerobic community to become established.

In addition, expanding areas of seafloor euxinia from both upper continental slopes (in response to oceanic OMZ expansion; Algeo et al., 2011a; Schoepfer et al., 2013) and mid-shelf regions (in response to nutrient loading; this study) may have created a 'euxinic pincher' that effectively killed off marine benthos over a wide range of water depths (perhaps 
$<100 \mathrm{~m}$ to $>500 \mathrm{~m})$. The shallowest regions of the ocean $(<20 \mathrm{~m})$ may have been affected by episodic shallowing of the chemocline (i.e., 'chemocline upward excursions' of Kump et al., 2005) or eruptions of $\mathrm{H}_{2} \mathrm{~S}$ into ocean-surface waters. Alternatively, much of the biotic stress in ocean-surface waters may have been due to intense climatic warming (Sun et al., 2012;

Song-HJ et al., 2014). Whatever mechanism is invoked must have operated quickly because fossil records demonstrate that extinction rates were low $(<30 \%)$ prior to the EPME and suddenly spiked to $90 \%$ at the EPME (Song-HJ et al., 2012). The speed with which this extinction event occurred is consistent with a pulse of nutrients derived from global warming and terrestrial ecosystem destruction causing rapid expansion of mid-shelf PZE.

\section{Conclusions}

Aryl isoprenoids (AI), biomarkers typical of obligate anaerobic green sulfur bacteria

(Chlorobiaceae), were detected in 12 Permian-Triassic boundary sections globally. Profiles of

AI abundance from these study sections reveal significant spatio-temporal variation, documenting the development of photic-zone euxinia (PZE) before, during, and after the end-Permian mass extinction (EPME). No AIs were identified in the shallowest sections, but

AIs are present in large amounts both prior to and following the mass extinction in intermediate-depth sections and following the mass extinction in deep-water sections, a pattern that is consistent with an oceanward expansion of PZE in the aftermath of the EPME. This expansion may have been fueled by an enhanced riverine nutrient flux as a result of global warming, terrestrial ecosystem destruction, and soil erosion, although intensified 
oceanic stratification as a function of climatic warming may have been a contributing factor. Marine euxinia is likely to have been a major player in the end-Permian mass extinction. Generation of a long-term reservoir of euxinic waters at intermediate ocean depths would have created the potential for episodic shallowing of the chemocline or eruptions of sulfidic waters into the ocean-surface layer. A major event of this type may have caused a rapid kill-off of shallow-marine benthos during the end-Permian mass extinction, and episodic expansion of PZE following the EPME may have been a factor delaying the recovery of Early Triassic marine ecosystems.

Acknowledgments
We thank Yong Lei, Zhenghui Xu, Chao Gao and Wanli Lin for field assistance in sampling. This work was supported by 973 Program (2011CB808800) and 111 Project (B08030), the National Natural Science Foundation of China (41202240, 41290262), and the Fundamental Research Founds for National University, China University of Geosciences (Wuhan) (grant No. 1610491T02). TJA gratefully acknowledges support from the Sedimentary Geology and Paleobiology program of the U.S. National Science Foundation, the NASA Exobiology program, and the China University of Geosciences-Wuhan (SKL-GPMR program GPMR201301, and SKL-BGEG program BGL201407).

\section{References}


Algeo, T.J., Ellwood, B.B., Nguyen, T.K.T., Rowe, H., Maynard, J.B., 2007. The Permian-Triassic boundary at Nhi Tao, Vietnam: evidence for recurrent influx of sulfidic watermasses to a shallow-marine carbonate platform. Palaeogeogr. Palaeoclimatol. Palaeoecol. 252, 304-327.

Algeo, T.J., Shen, Y., Zhang, T., Lyons, T., Bates, S., Rowe, H., Nguyen, T., 2008. Association of ${ }^{34} \mathrm{~S}$-depleted pyrite layers with negative carbonate $\delta^{13} \mathrm{C}$ excursions at the Permian-Triassic boundary: Evidence for upwelling of sulfidic deep-ocean water masses.

Algeo, T.J., Kuwahara, K., Sano, H., Bates, S., Lyons, T., Elswick, E., Hinnov, L., Ellwood, B., Moser, J., Maynard, J.B., 2011a. Spatial variation in sediment fluxes, redox conditions, and productivity in the Permian-Triassic Panthalassic Ocean. Palaeogeogr. Palaeoclimatol. Palaeoecol. 308, 65-83.

Algeo, T.J., Chen, Z.Q., Fraiser, M.L., Twitchett, R.J., 2011b. Terrestrial-marine teleconnections in the collapse and rebuilding of Early Triassic marine ecosystems. Palaeogeogr. Palaeoclimatol. Palaeoecol. 308, 1-11.

Algeo, T.J., Henderson, C.M., Ellwood, B., Rowe, H., Elswick, E., Bates, S., Lyons, T., Hower, J.C., Smith, C., Maynard, B., 2012. Evidence for a diachronous Late Permian marine crisis from the Canadian Arctic region. Geol. Soc. Am. Bull. 124, 1424-1448.

Algeo, T.J., Henderson, C.M., Tong, J., Feng, Q., Yin, H., Tyson, R., 2013. Plankton and productivity during the Permian-Triassic boundary crisis: An analysis of organic carbon fluxes. Glob. Planet. Chang. 105, 52-67. 
Bond, D.P.,Wignall, P.B., 2010. Pyrite framboid study of marine Permian-Triassic boundary sections: a complex anoxic event and its relationship to contemporaneous mass extinction. Geol. Soc. Am. Bull. 122, 1265-1279.

Brennecka, G.A., Herrmann, A.D., Algeo, T.J., Anbar, A.D., 2011. Rapid expansion of oceanic anoxia immediately before the end-Permian mass extinction. Proc. Natl. Acad. Sci. USA 108, 17631-17634.

Brett, C.E., Boucot, A.J., Jones, B., 1993. Absolute depths of Silurian benthic assemblages. Lethaia 26, 25-40.

Campbell, I., Czamanske, G., Fedorenko, V., Hill, R., Stepanov, V., 1992. Synchronism of the Siberian Traps and the Permian-Triassic boundary. Science 258, 1760-1763.

Cao, C., Love, G.D., Hays, L.E., Wang, W., Shen, S., Summons, R.E., 2009. Biogeochemical evidence for euxinic oceans and ecological disturbance presaging the end-Permian mass extinction event. Earth Planet. Sci. Lett. 281, 188-201.

Chafetz, H., Reid, A., 2000. Syndepositional shallow-water precipitation of glauconitic minerals. Sed. Geol. 136, 29-42.

Chen, Z.Q., Tong, J., Kaiho, K., Kawahata, H., 2007. Onset of biotic and environmental recovery from the end-Permian mass extinction within 1-2 million years: A case study of the Lower Triassic of the Meishan section, South China. Palaeogeogr. Palaeoclimatol. Palaeoecol. 252, 176-187.

Chen, Z.Q., Tong, J., Zhang, K., Yang, H., Liao, Z., Song, H.J., Chen, J., 2009. Environmental and biotic turnover across the Permian-Triassic boundary on a shallow carbonate platform in western Zhejiang, South China. Austral. J. Earth Sci. 56, 775-797. 
Chen, Z.Q., Tong, J., Liao, Z.T., Chen, J., 2010. Structural changes of marine communities over the Permian-Triassic transition: ecologically assessing the end-Permian mass extinction and its aftermath. Glob. Planet. Chang. 73, 123-140.

Chen, Z.Q., Tong, J., Fraiser, M.L., 2011. Trace fossil evidence for restoration of marine ecosystems following the end-Permian mass extinction in the Lower Yangtze region, South China. Palaeogeogr. Palaeoclimatol. Palaeoecol. 299, 449-474.

Chen, Z.Q., Yang, H., Luo, M., Benton, M.J., Kaiho, K., Zhao, L.S, Huang, Y., Zhang, K.X., Fang, Y., Jiang, H.S., Qiu, H., Li, Y., Tu, C.Y., Shi, L., Zhang, L., Feng, X.Q., Chen, L., 2015. Complete biotic and sedimentary records of the Permian-Triassic transition from Meishan section, South China: ecologically assessing mass extinction and its aftermath. Earth-Sci. Rev._149, 63-103.

Clarkson, M.O., Kasemann, S.A., Wood, R.A., Lenton, T.M., Daines, S.J., Richoz, S., Ohnemueller, F., Meixner, A., Poulton, S.W., Tipper, E.T., 2015. Ocean acidification and the Permo-Triassic mass extinction. Science 348, 229-232.

Erwin, D.H., Bowring, S.A., Jin, Y., 2002. End-Permian mass extinctions: a review. In: Koeberl, C., MacLeod, K.G. (Eds.), Catastrophic Events and Mass Extinctions: Impacts and Beyond: Boulder, Colorado, Geological Society of America Special Paper 356, pp. $363-383$.

Ezaki, Y., Liu, J., Adachi, N., 2003. Earliest Triassic microbialite micro-to megastructures in the Huaying area of Sichuan Province, South China: implications for the nature of oceanic conditions after the end-Permian extinction. Palaios 18, 388-402.

Farabegoli, E., Perri, M.C., Posenato, R., 2007. Environmental and biotic changes across the 

Planet. Chang. 55, 109-135.

Feng, Q., Algeo, T.J., 2014. Evolution of oceanic redox conditions during the Permo-Triassic transition: Evidence from deepwater radiolarian facies. Earth-Sci. Rev. 137, 34-51.

Fenton, S., Grice, K., Twitchett, R.J., Böttcher, M.E., Looy, C.V., Nabbefeld, B., 2007. Changes in biomarker abundances and sulfur isotopes of pyrite across the Permian-Triassic (P/Tr) Schuchert Dal section (East Greenland). Earth Planet. Sci. Lett. $262,230-239$.

French, K.L., Tosca, N.J., Cao, C., Summons, R.E., 2012. Diagenetic and detrital origin of moretane anomalies through the Permian-Triassic boundary. Geochim. Cosmochim. Acta $84,104-125$.

Gorjan, P., Kaiho, K., Kakegawa, T., Niitsuma, S., Chen, Z.Q., Kajiwara, Y., Nicora, A., 2007. Paleoredox, biotic and sulfur-isotopic changes associated with the end-Permian mass extinction in the western Tethys. Chem. Geol. 244, 483-492.

Grice, K., Schaeffer, P., Schwark, L., Maxwell, J.R., 1996. Molecular indicators of palaeoenvironmental conditions in an immature Permian shale (Kupferschiefer, Lower Rhine Basin, north-west Germany) from free and S-bound lipids. Org. Geochem. 25, $131-147$.

Grice, K., Cao, C., Love, G.D., Böttcher, M.E., Twitchett, R.J., Grosjean, E., Summons, R.E., Turgeon, S.C., Dunning, W., Jin, Y., 2005a. Photic zone euxinia during the Permian-Triassic superanoxic event. Science 307, 706-709.

Grice, K., Twitchett, R.J., Alexander, R., Foster, C., Looy, C., 2005b. A potential biomarker 
596

Grice, K., Nabbefeld, B., Maslen, E., 2007. Source and significance of selected polycyclic aromatic hydrocarbons in sediments (Hovea-3 well, Perth Basin, Western Australia) spanning the Permian-Triassic boundary. Org. Geochem. 38, 1795-1803.

Hays, L.E., Beatty, T., Henderson, C.M., Love, G.D., Summons, R.E., 2007. Evidence for photic zone euxinia through the end-Permian mass extinction in the Panthalassic Ocean (Peace River Basin, Western Canada). Palaeoworld 16, 39-50.

Hays, L.E., Grice, K., Foster, C.B., Summons, R.E., 2012. Biomarker and isotopic trends in a Permian-Triassic sedimentary section at Kap Stosch, Greenland. Org. Geochem. 43,

$$
\text { 67-82. }
$$

He, W., Feng, Q., Gu, S., Jin, Y., 2005. Changxingian (Upper Permian) radiolarian fauna from Meishan D section, Changxing, Zhejiang, China, and its possible paleoecological significance. J. Paleontol. 79, 209-218.

Hermann, E., Hochuli, P.A., Bucher, H., Brühwiler, T., Hautmann, M., Ware, D., Weissert, H., Roohi, G., Yaseen, A., 2012. Climatic oscillations at the onset of the Mesozoic inferred from palynological records from the North Indian Margin. J. Geol. Soc. London 169,

$$
227-237 \text {. }
$$

Hine, A.C., 1977. Lily Bank, Bahamas: history of an active oolite sand shoal. J. Sed. Res. 47, $1554-1582$.

Hinojosa, J.L., Brown, S.T., Chen, J., DePaolo, D.J., Paytan, A., Shen, S.Z., Payne, J.L., 2012. Evidence for end-Permian ocean acidification from calcium isotopes in biogenic apatite. Geology 40, 743-746. 
617 Isozaki, Y., 1997. Permo-Triassic boundary superanoxia and stratified superocean: records 618 from lost deep sea. Science 276, 235-238.

619 Jaraula, C.M., Grice, K., Twitchett, R.J., Böttcher, M.E., LeMetayer, P., Dastidar, A.G., Opazo, 620 L.F., 2013. Elevated $p \mathrm{CO}_{2}$ leading to Late Triassic extinction, persistent photic zone $621 \quad$ euxinia, and rising sea levels. Geology 41, 955-958.

622

Jiang, H., Lai, X., Yan, C., Aldridge, R.J., Wignall, P., Sun, Y., 2011. Revised conodont zonation and conodont evolution across the Permian-Triassic boundary at the Shangsi section, Guangyuan, Sichuan, south China. Glob. Planet. Chang. 77, 103-115.

Joachimski, M.M., Lai, X., Shen, S., Jiang, H., Luo, G., Chen, B., Chen, J., Sun, Y., 2012. Climate warming in the latest Permian and the Permian-Triassic mass extinction. Geology 40, 195-198.

Kaiho, K., 1994. Benthic foraminiferal dissolved-oxygen index and dissolved-oxygen levels in the modern ocean. Geology 22, 719-722.

Kaiho, K., Kajiwara, Y., Chen, Z.Q., Gorjan, P., 2006. A sulfur isotope event at the end of the Permian. Chem. Geol. 235, 33-47.

Kaiho, K., Oba, M., Fukuda, Y., Ito, K., Ariyoshi, S., Gorjan, P., Riu, Y., Takahashi, S., Chen, Z.Q., Tong, J., 2012. Changes in depth-transect redox conditions spanning the end-Permian mass extinction and their impact on the marine extinction: Evidence from biomarkers and sulfur isotopes. Glob. Planet. Chang. 94, 20-32.

Kamo, S.L., Czamanske, G.K., Amelin, Y., Fedorenko, V.A., Davis, D.W., Trofimov, V.R., 2003. Rapid eruption of Siberian flood-volcanic rocks and evidence for coincidence with the Permian-Triassic boundary and mass extinction at 251 Ma. Earth Planet. Sci. Lett. 
640 Kato, Y., Nakao, K., Isozaki, Y., 2002. Geochemistry of Late Permian to Early Triassic pelagic cherts from southwest Japan: implications for an oceanic redox change. Chem. Geol. 182, 15-34.

643

644

645

646

647

648

649

650

651

652

653

654

655

656

657

658

659

660

Kershaw, S., Crasquin, S., Li, Y., Collin, P.Y., Forel, M.B., Mu, X., Baud, A., Wang, Y., Xie, S., Maurer, F., 2012. Microbialites and global environmental change across the Permian-Triassic boundary: a synthesis. Geobiology 10, 25-47.

Knoll, A.H., Bambach, R.K., Payne, J.L., Pruss, S., Fischer, W.W., 2007. Paleophysiology and end-Permian mass extinction. Earth Planet. Sci. Lett. 256, 295-313.

Koopmans, M.P., Köster, J., Van Kaam-Peters, H.M., Kenig, F., Schouten, S., Hartgers, W.A., de Leeuw, J.W., Sinninghe Damsté, J.S., 1996. Diagenetic and catagenetic products of isorenieratene: molecular indicators for photic zone anoxia. Geochim. Cosmochim. Acta 60, 4467-4496.

Korte, C., Kozur, H.W., Bruckschen, P., Veizer, J., 2003. Strontium isotope evolution of Late Permian and Triassic seawater. Geochim. Cosmochim. Acta 67, 47-62.

Korte, C., Pande, P., Kalia, P., Kozur, H.W., Joachimski, M.M., Oberhänsli, H., 2010. Massive volcanism at the Permian-Triassic boundary and its impact on the isotopic composition of the ocean and atmosphere. J. Asian Earth Sci. 37, 293-311.

Kump, L.R., Pavlov, A., Arthur, M.A., 2005. Massive release of hydrogen sulfide to the surface ocean and atmosphere during intervals of oceanic anoxia. Geology 33, 397-400.

Lai, X.L.., Yang, F.Q., Hallam, A., Wignall, P., 1996. The Shangsi section, candidate of the global stratotype section and point of the Permian-Triassic boundary. In: Yin, H.F. (Ed.), 
Li, Z.S., Zhan, L.P., Zhu, X.F., Zhang, J.H., Jin, R., Liu, G., Sheng, H., Shen, G., Dai, J., Mesozoic era. Acta Geol. Sin. 60, 1-15.

Liao, W., Wang, Y., Kershaw, S., Weng, Z., Yang, H., 2010. Shallow-marine dysoxia across the Permian-Triassic boundary: Evidence from pyrite framboids in the microbialite in South China. Sediment. Geol. 232, 77-83.

Loope, G.R., Kump, L.R., Arthur, M.A., 2013. Shallow water redox conditions from the Permian-Triassic boundary microbialite: The rare earth element and iodine geochemistry 2013. Microbial-algal community changes during the latest Permian ecological crisis: Evidence from lipid biomarkers at Cili, South China. Glob. Planet. Chang. 105, 36-51. during the end-Permian mass extinction. Palaeogeogr. Palaeoclimatol. Palaeoecol. 396, $119-131$.

Meyer, K.M., Kump, L.R., 2008. Oceanic euxinia in Earth history: causes and consequences. Annu. Rev. Earth Planet. Sci. 36, 251-288. 
684

685

686

687

688

689

690

691

692

693

694

695

696

697

698

699

700

701

702

Monteiro, F., Pancost, R., Ridgwell, A., Donnadieu, Y., 2012. Nutrients as the dominant control on the spread of anoxia and euxinia across the Cenomanian-Turonian oceanic anoxic event (OAE2): Model-data comparison. Paleoceanogr. 27, PA4209, doi:10.1029/2012PA002351.

Mørk, A., Elvebakk, G., Forsberg, A.W., Vigran, J.O., Weitschat, W., 1999. The type section of the Vikinghogda Formation: a new Lower Triassic unit in central and eastern Svalbard. Polar Res. 18, 51-82.

Nabbefeld, B., Grice, K., Summons, R.E., Hays, L.E., Cao, C., 2010a. Significance of polycyclic aromatic hydrocarbons (PAHs) in Permian/Triassic boundary sections. Applied Geochem. 25, 1374-1382.

Nabbefeld, B., Grice, K., Twitchett, R.J., Summons, R.E., Hays, L., Böttcher, M.E., Asif, M., 2010b. An integrated biomarker, isotopic and palaeoenvironmental study through the Late Permian event at Lusitaniadalen, Spitsbergen. Earth Planet. Sci. Lett. 291, 84-96.

Naeher, S., Grice, K., 2015. Novel 1H-Pyrrole-2, 5-dione (maleimide) proxies for the assessment of photic zone euxinia. Chem. Geol. 404, 100-109.

Nicoll, R.S., Metcalfe, I., Wang, C.Y., 2002. New species of the conodont genus Hindeodus and the conodont biostratigraphy of the Permian-Triassic boundary interval. J. Asian Earth Sci. 20, 609-631.

Overmann, J., 2008. Ecology of phototrophic sulfur bacteria. In: Hell, R., Dahl, C., Knaff, D.B., Leustek, T. (Eds), Sulfur Metabolism in Phototrophic Organisms. Springer, Berlin/Heidelberg, pp. 375-396. 
705

706

707

708

709

710

711

712

713

714

715

716

717

718

719

720

721

722

Overmann, J., Tuschak, C., 1997. Phylogeny and molecular fingerprinting of green sulfur bacteria. Arch. Microbiol. 167, 302-309.

Pastorova, I., Botto, R.E., Arisz, P.W., Boon, J.J., 1994. Cellulose char structure: a combined analytical Py-GC-MS, FTIR, and NMR study. Carbohydr. Res. 262, 27-47.

Perri, M., 1991. Conodont biostratigraphy of the Werfen Formation (Lower Triassic), Southern Alps, Italy. Boll. Soc. Paleontol. Ital. 30, 23-46.

Plet, C., Grice, K., Pagès, A., Ruebsam, W., Coolen, M., Schwark, L., 2016. Microbially-mediated fossil-bearing carbonate concretions and their significance for palaeoenvironmental reconstructions: A multi-proxy organic and inorganic geochemical appraisal. Chem. Geol. 426, 95-108.

Reichow, M.K., Pringle, M., Al'Mukhamedov, A., Allen, M., Andreichev, V., Buslov, M., Davies, C., Fedoseev, G., Fitton, J., Inger, S., 2009. The timing and extent of the eruption of the Siberian Traps large igneous province: Implications for the end-Permian environmental crisis. Earth Planet. Sci. Lett. 277, 9-20.

Riccardi, A., Kump, L.R., Arthur, M.A., D'Hondt, S., 2007. Carbon isotopic evidence for chemocline upward excursions during the end-Permian event. Palaeogeogr. Palaeoclimatol. Palaeoecol. 248, 73-81.

Romano, C., Goudemand, N., Vennemann, T.W., Ware, D., Schneebeli-Hermann, E., Hochuli, P.A., Brühwiler, T., Brinkmann, W., Bucher, H., 2013. Climatic and biotic upheavals following the end-Permian mass extinction. Nat. Geosci. 6, 57-60.

Schoepfer, S.D., Henderson, C.M., Garrison, G.H., Foriel, J., Ward, P.D., Selby, D., Hower, J.C., Algeo, T.J., Shen, Y., 2013. Termination of a continent-margin upwelling system at 
the Permian-Triassic boundary (Opal Creek, Alberta, Canada). Glob. Planet. Chang. 105, $21-35$.

Sedlacek, A.R., Saltzman, M.R., Algeo, T.J., Horacek, M., Brandner, R., Foland, K., Denniston, R.F., 2014. ${ }^{87} \mathrm{Sr} /{ }^{86} \mathrm{Sr}$ stratigraphy from the Early Triassic of Zal, Iran: Linking temperature to weathering rates and the tempo of ecosystem recovery. Geology 42, 779-782.

Sephton, M.A., Looy, C.V., Brinkhuis, H., Wignall, P.B., De Leeuw, J.W., Visscher, H., 2005. Catastrophic soil erosion during the end-Permian biotic crisis. Geology 33, 941-944.

Shen, J., Schoepfer, S.D., Feng, Q.L., Zhou, L., Yu, J., Song, H.Y., Wei, H.Y., Algeo, T.J., 2015. Marine productivity changes during the Permian-Triassic boundary crisis and Early Triassic recovery. Earth-Sci. Rev. 149, 136-162.

Shen, S.-Z., Crowley, J.L., Wang, Y., Bowring, S.A., Erwin, D.H., Sadler, P.M., Cao, C.-Q., Rothman, D.H., Henderson, C.M., Ramezani, J., 2011. Calibrating the end-Permian mass extinction. Science 334, 1367-1372.

Sinninghe Damsté, J.S., Schouten, S., 2006. Biological markers for anoxia in the photic zone of the water column. In: Volkman, J. (Ed.), Marine Organic Matter: Biomarkers, Isotopes and DNA. The Handbook of Environmental Chemistry. Springer, Berlin/Heidelberg, pp. $127-163$.

Song, H.J., Tong, J.-N., Zhang, K.-X., Wang, Q.-X., Chen, Z., 2007. Foraminiferal survivors from the Permian-Triassic mass extinction in the Meishan section, South China. Palaeoworld 16, 105-119.

Song, H.J., Wignall, P.B., Tong, J., Yin, H., 2012. Two pulses of extinction during the 
750

760

761

762

Song, H.J., Wignall, P.B., Chu, D., Tong, J., Sun, Y., Song, H., He, W., Tian, L., 2014. Anoxia/high temperature double whammy during the Permian-Triassic marine crisis and its aftermath. Sci. Rep. 4, 4132e.

Song, H.Y., Tong, J., Algeo, T.J., Horacek, M., Qiu, H., Song, H.J., Tian, L., Chen, Z.Q., 2013. Large vertical $\delta^{13} \mathrm{C}_{\mathrm{DIC}}$ gradients in Early Triassic seas of the South China craton: Implications for oceanographic changes related to Siberian Traps volcanism. Glob. Planet. Chang. 105, 7-20.

Song, H.Y., Tong, J., Tian, L., Song, H.J., Qiu, H., Zhu, Y., Algeo, T.J., 2014. Paleo-redox conditions across the Permian-Triassic boundary in shallow carbonate platform of the Nanpanjiang Basin, South China. Sci. China D: Earth Sci. 57, 1030-1038.

Summons, R.E., Powell, T.G., 1986. Chlorobiaceae in Palaeozoic seas revealed by biological markers, isotopes and geology. Nature 319, 763-765.

Summons, R., Powell, T., 1987. Identification of aryl isoprenoids in source rocks and crude oils: biological markers for the green sulphur bacteria. Geochim. Cosmochim. Acta 51, $557-566$.

Sun, Y., Joachimski, M.M., Wignall, P.B., Yan, C., Chen, Y., Jiang, H., Wang, L., Lai, X., 2012. Lethally hot temperatures during the Early Triassic greenhouse. Science 338, $366-370$.

Svensen, H., Planke, S., Polozov, A.G., Schmidbauer, N., Corfu, F., Podladchikov, Y.Y., Jamtveit, B., 2009. Siberian gas venting and the end-Permian environmental crisis. Earth Planet. Sci. Lett. 277, 490-500. 
Takahashi, S., Yamasaki, S.-i., Ogawa, Y., Kimura, K., Kaiho, K., Yoshida, T., Tsuchiya, N., 2014. Bioessential element-depleted ocean following the euxinic maximum of the end-Permian mass extinction. Earth Planet. Sci. Lett. 393, 94-104.

Teichert, C., Kummel, B., 1972. Permian-Triassic boundary in the Kap Stosch area, east Greenland. Bull. Canadian Petrol. Geol. 20, 659-675.

Thomas, B., Willink, R., Grice, K., Twitchett, R., Purcell, R., Archbold, N., George, A., Tye, S., Alexander, R., Foster, C., 2004. Unique marine Permian-Triassic boundary section from Western Australia. Austral. J. Earth Sci. 51, 423-430.

Tian, S.F., Chen, Z.Q., Huang, C.J., 2014. Orbital forcing and sea-level changes in the earliest Triassic of the Meishan section, South China. J. Earth Sci. (China Univ. Geosci.-Wuhan) $25,64-73$.

Tong, J., Zhao, L., 2011. Lower Triassic and Induan-Olenekian Boundary in Chaohu, Anhui Province, South China. Acta Geol. Sin. (English edition) 85, 399-407.

Wang, C., Visscher, H., 2007. Abundance anomalies of aromatic biomarkers in the Permian-Triassic boundary section at Meishan, China—evidence of end-Permian terrestrial ecosystem collapse. Palaeogeogr. Palaeoclimatol. Palaeoecol. 252, 291-303.

Wang, Q., Tong, J., Song, H.J., Yang, H., 2009. Ecological evolution across the Permian/Triassic boundary at the Kangjiaping Section in Cili County, Hunan Province, China. Sci. China D: Earth Sci. 52, 797-806.

Wei, H.Y., Shen, J., Schoepfer, S.D., Krystyn, L., Richoz, S., Algeo, T.J., 2015. Environmental controls on marine ecosystem recovery following mass extinctions, with an example from the Early Triassic. Earth-Sci. Rev. 149, 108-135. 
793

794

795

796

797

798

799

800

801

802

803

804

805

806

807

808

809

810

811

812

813 814 Autonomous Region, South China and their paleoenvironmental implications. J. Earth

Whiteside, J.H., Grice, K., 2016. Biomarker records associated with mass extinction events. Annu. Rev. Earth Planet. Sci. 44, in press.

Wignall, P.B., Hallam, A., Lai, X.L., Yang, F.Q., 1995. Palaeoenvironmental changes across the Permian/Triassic boundary at Shangsi (N. Sichuan, China). Historical Biology 10, $175-189$.

Wignall, P., Hallam, A., 1996. Facies change and the end-Permian mass extinction in SE Sichuan, China. Palaios 11, 587-596.

Wignall, P.B., Twitchett, R.J., 1996. Oceanic anoxia and the end Permian mass extinction. Science 272, 1155-1158.

Winguth, C., Winguth, A.M.E., 2012. Simulating Permian-Triassic oceanic anoxia distribution: implications for species extinction and recovery. Geology 40(2), 127-130.

Xie, S., Pancost, R.D., Yin, H., Wang, H., Evershed, R.P., 2005. Two episodes of microbial change coupled with Permo/Triassic faunal mass extinction. Nature 434, 494-497.

Xie, S., Pancost, R.D., Huang, J., Wignall, P.B., Yu, J., Tang, X., Chen, L., Huang, X., Lai, X., 2007. Changes in the global carbon cycle occurred as two episodes during the Permian-Triassic crisis. Geology 35, 1083-1086.

Yang, H., Chen, Z.Q., Wang, Y., Tong, J., Song, H.J., Chen, J., 2011. Composition and structure of microbialite ecosystems following the end-Permian mass extinction in South China. Palaeogeogr. Palaeoclimatol. Palaeoecol. 308, 111-128.

Yang, H., Chen, Z.Q., Ou, W.Q., 2015a. Microconchids from microbialites near the

13 Permian-Triassic boundary in the Zuodeng section, Baise area, Guangxi Zhuang 
816

Yang, H., Chen, Z.Q., Wang, Y., Ou, W.Q., Liao, W., Mei, X., 2015b. Microconchids from microbialite ecosystem immediately after end-Permian mass extinction: ecologic selectivity and implications for microbialite ecosystem structure. Lethaia 48, 497-508.

Yin, H.F., Zhang, K.X., Tong, J.N., Yang, Z.Y., Wu, S.B., 2001. The global stratotype section and point (GSSP) of the Permian-Triassic boundary. Episodes 24, 102-114.

Yin, H.F., Jiang, H., Xia, W., Feng, Q., Zhang, N., Shen, J., 2014. The end-Permian regression in South China and its implication on mass extinction. Earth-Sci. Rev. 137, 19-33.

Zhang, K., Tong, J., Yin, H., Wu, S., 1996. Sequence stratigraphy near the Permian-Triassic boundary at Meishan section, South China. In: Yin, H.F. (Ed.), The Palaeozoic-Mesozoic Boundary Candidates of Global Stratotype Section and Point of the Permian-Triassic Boundary. China University of Geosciences Press, Wuhan, pp. 72-83.

Zhao, L.S., Orchard, M.J., Tong, J.N., Sun, Z.M., Zuo, J.X., Zhang, S.X., Yun, A.L., 2007. Lower Triassic conodont sequence in Chaohu, Anhui Province, China and its global correlation. Palaeogeogr. Palaeoclimatol. Palaeoecol. 252, 24-38.

\section{Figure captions}

Fig. 1. Latest Permian paleogeography of world (A) and South China block (B), showing locations of the study sections: LLD - Laolongdong, CL - Cili, BL - Bulla, PRB - Peace River Basin, WBF - West Blind Fjord, KS - Kap Stosch, SP - Spitsbergen, PB - Perth Basin. 
MS - Meishan, HZS - Huangzhishan. SS - Shangsi, CH - Chaohu. Note that, relative to its modern orientation (A), the South China craton was rotated nearly $90^{\circ}$ counter-clockwise during the latest Permian (B); all references in the text to compass orientations are based on Permian-Triassic paleogeography. Estimated water depths for study sections in continental shelf (C) and ramp settings (D). FWWB - fair-weather wave base, SWB - storm wave base.

Fig. 2. (Top) Molecular structure of aromatic carotenoids (chlorobactene and isorenieratene).

(Middle) Breakdown sequence leading to AIs. (Bottom) Structures of moretanes, fluorenes, DBF, DBT, BaP, and BeP.

Hindeodus, $I .=$ Isarcicella,$N .=$ Neoclarkina.

Fig. 4. Profiles of the abundance of aryl isoprenoids (AI, $\mu \mathrm{g} / \mathrm{g}$ TOC) derived from green sulfur bacteria and the relative abundance of $\mathrm{DBF}($ i.e., $\mathrm{DBF} /(\mathrm{DBF}+\mathrm{DBT}+\mathrm{F}))$ derived from terrestrial organic matter inputs. The blue and red lines represent the EPME and PTB horizons, respectively. Data source: this study. Abbreviations for biozones (based on conodonts except as noted): L. p. and U.p. - lower and upper Hindeodus praeparvus, H. p. - 
Fig. 5. Profiles of the abundance of aryl isoprenoids (AI, $\mu \mathrm{g} / \mathrm{g}$ TOC) derived from green sulfur bacteria and data derived from terrestrial organic matter inputs (i.e., DBF abundance). Data sources: Peace River Basin (Hays et al., 2007), Kap Stosch (Hays et al., 2012), Spitsbergen (Nabbefeld et al., 2010b), West Blind Fiord (Algeo et al., 2012), Perth Basin (Grice et al., 2005a; Thomas et al., 2004), Huangzhishan (Kaiho et al., 2012), Meishan (AI from Cao et al., 2009; $\mathrm{C}_{30} \mathrm{M} / \mathrm{C}_{30} \mathrm{HP}$ from Cao et al., 2009 (yellow) and Xie et al., 2007 (white)). Conodont zones: C. m. - Clarkina meishanensis, H. c. - Hindeodus changxingensis, I. l. - Isarcicella lobata, H. t. - H. typicalis, C. ch. - C. changxingensis, C. t. - C. taylorae, M. s. - Mesogondolella sheni, C. h.-C. ch. - C. hauschkei-C. changxingensis. Other details as in Figure 2.
Fig. 6. Profiles of the abundance of aryl isoprenoids (AI, $\mu \mathrm{g} / \mathrm{g}$ TOC) derived from green sulfur bacteria and data derived from terrestrial organic matter inputs (i.e., DBF abundance). Data sources: Chaohu (Kaiho et al., 2012; red points, this study), Shangsi (this study). AI and DBT abundances for Chaohu have been normalized to phenanthrene (Phe). Other details as in Figure 2.

Fig. 7. Relationship of aryl isoprenoids (AI, $\mu \mathrm{g} / \mathrm{g}$ TOC) to moretanes $\left(\mathrm{C}_{30} \mathrm{M} / \mathrm{C}_{30} \mathrm{HP}\right)(\mathrm{A})$ and isorenieratane ( $\mu \mathrm{g} / \mathrm{g}$ TOC) to AI ( $\mu \mathrm{g} / \mathrm{g}$ TOC)(B) at Shangsi (SS). The blue and red dots represent pre-EPME and post-EPME samples, respectively.

Fig. 8. Expansion of photic-zone euxinia during the Permian-Triassic biotic crisis. Gray and 
881 green shaded areas represent euxinia in the pre-EPME and post-EPME intervals, respectively 882 (A and B); black dots represent primary productivity (C, D, and E).

885 Table 1. Paleogeographic and paleoenvironmental characteristics of the 12 study sections 886 


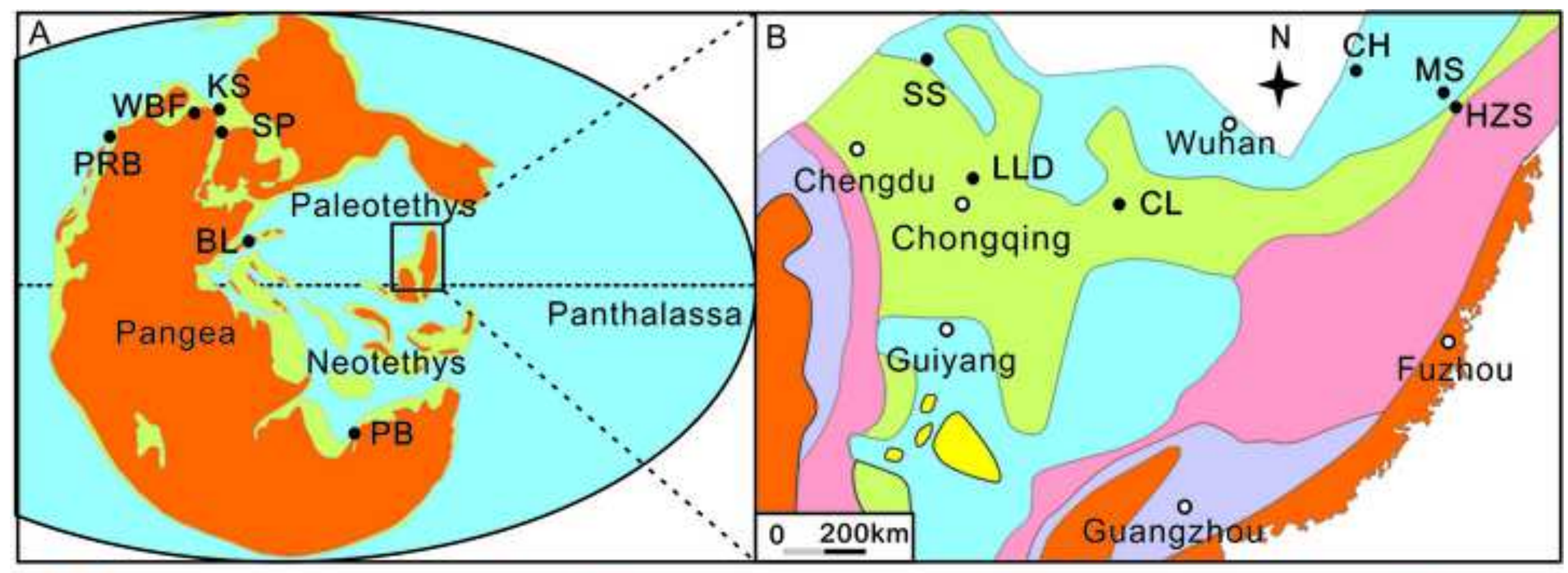

$\square$ Land $\square$ Alluvial facies $\square$ Neritic clastic facies $\square$ Carbonate platform $\square$ Basin

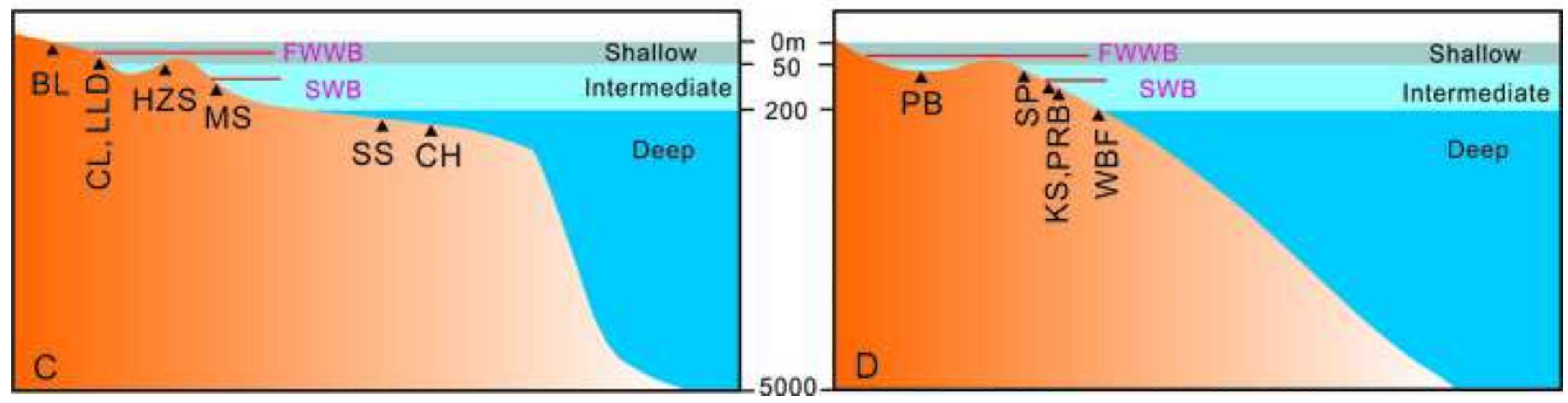



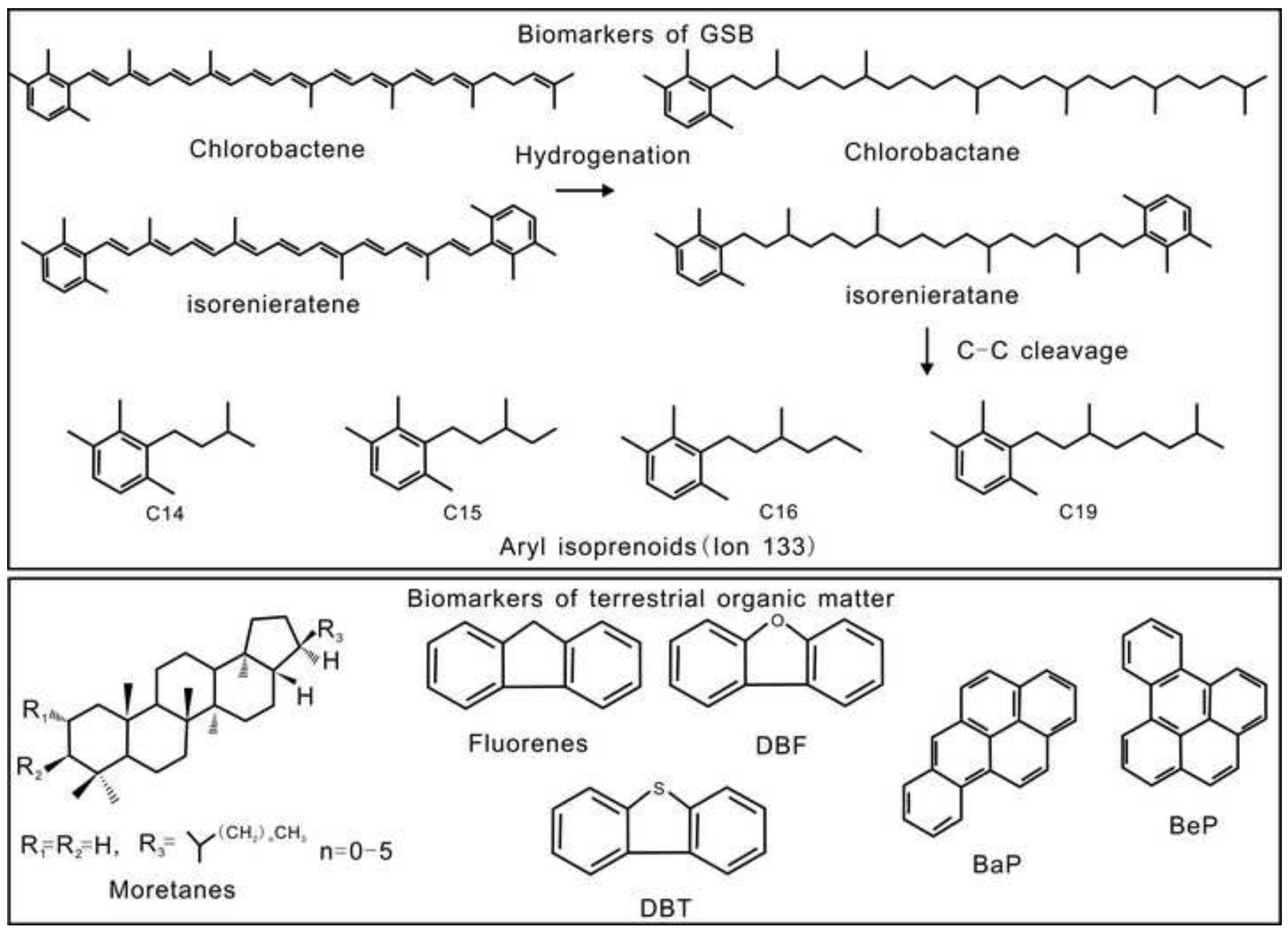

\section{Chlorobactene}

Hydrogenation

Chlorobactane

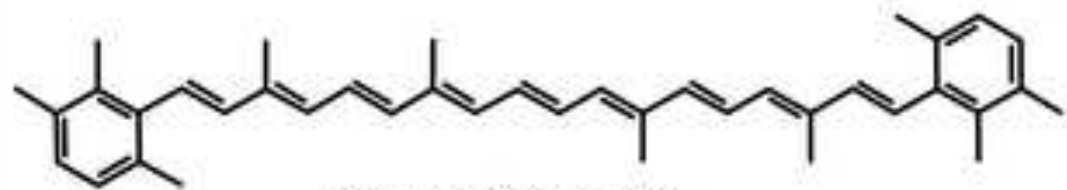
isorenieratene
C16
C19

Biomarkers of terrestrial organic matter

Fluorenes

DBT 


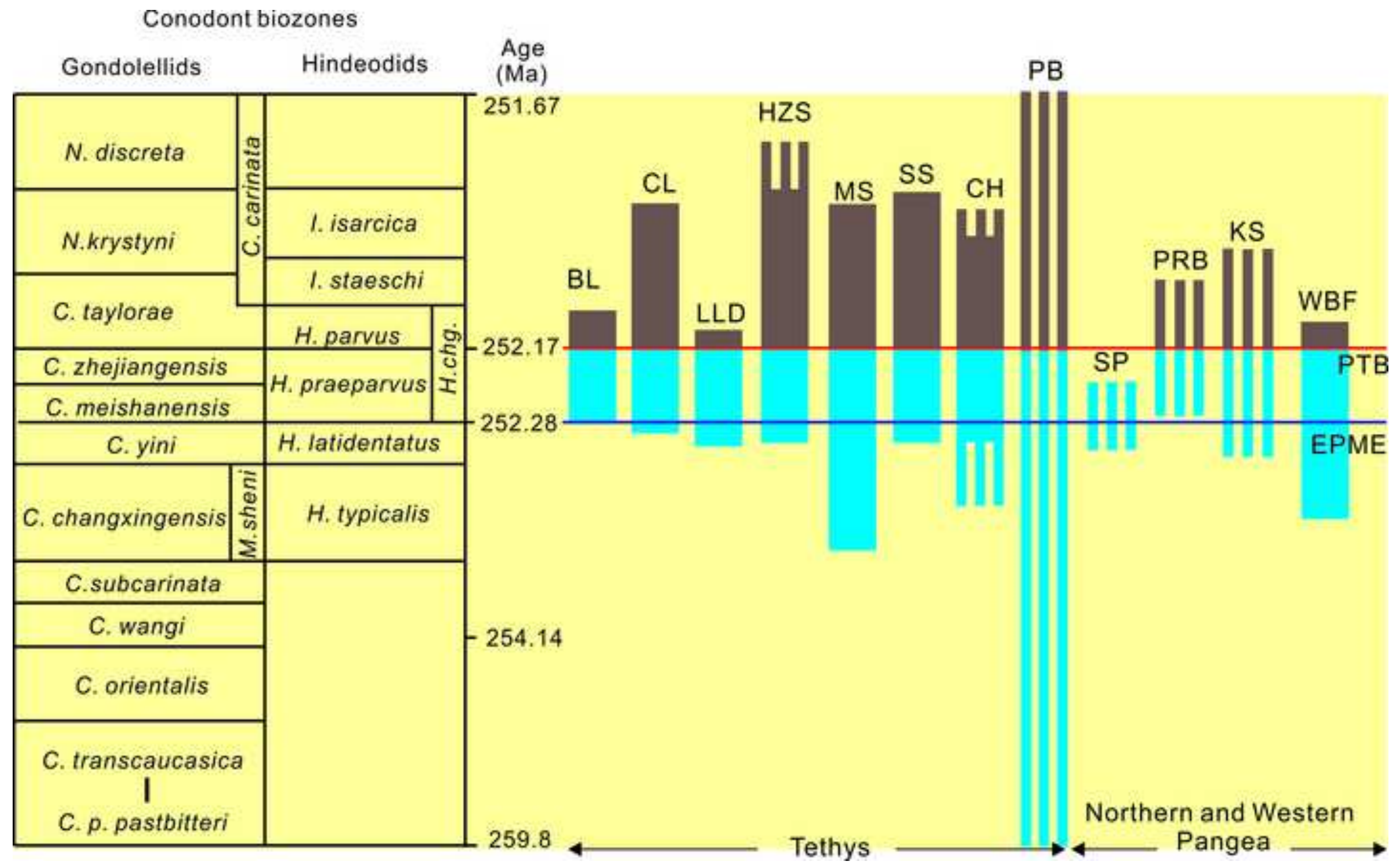




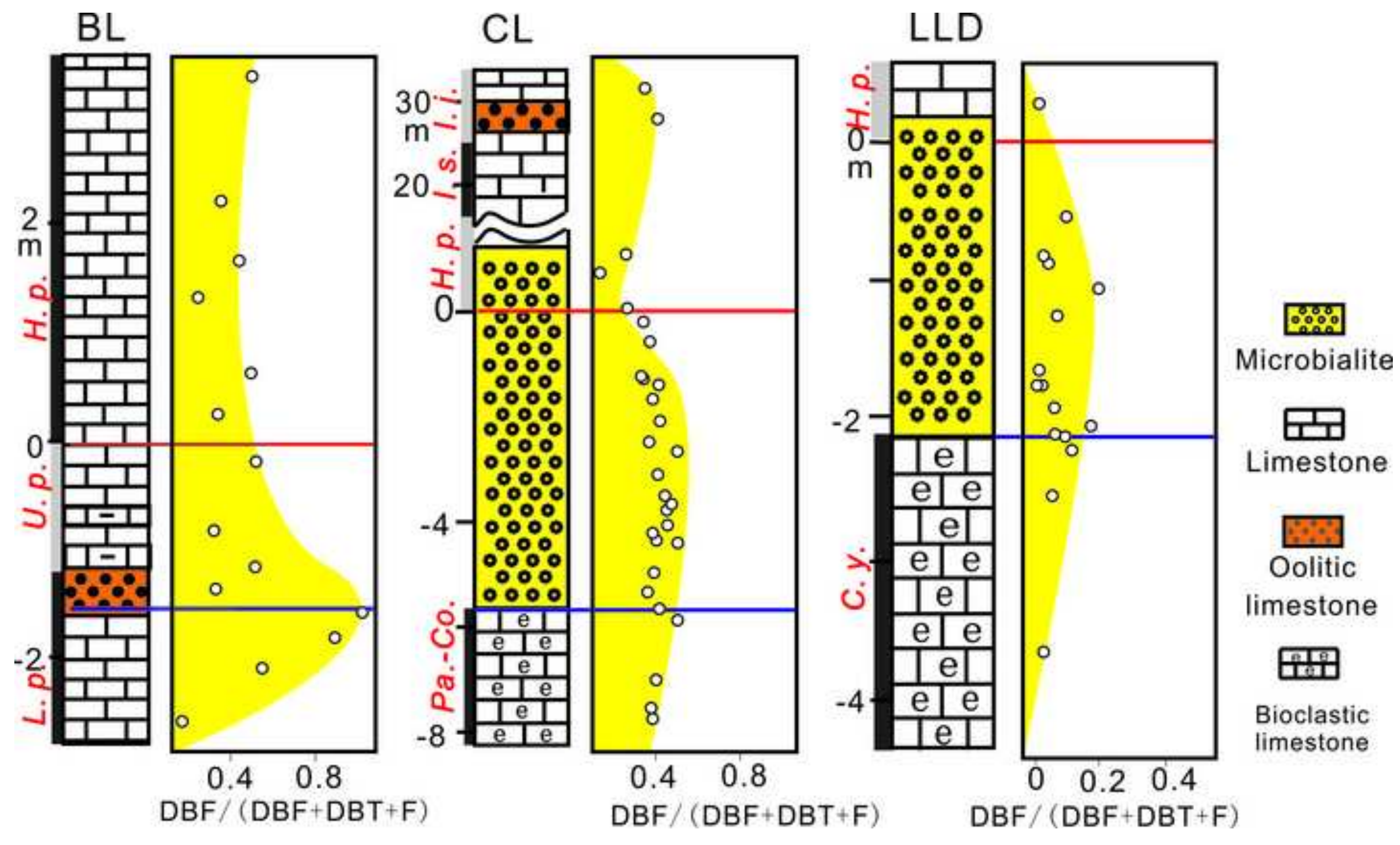



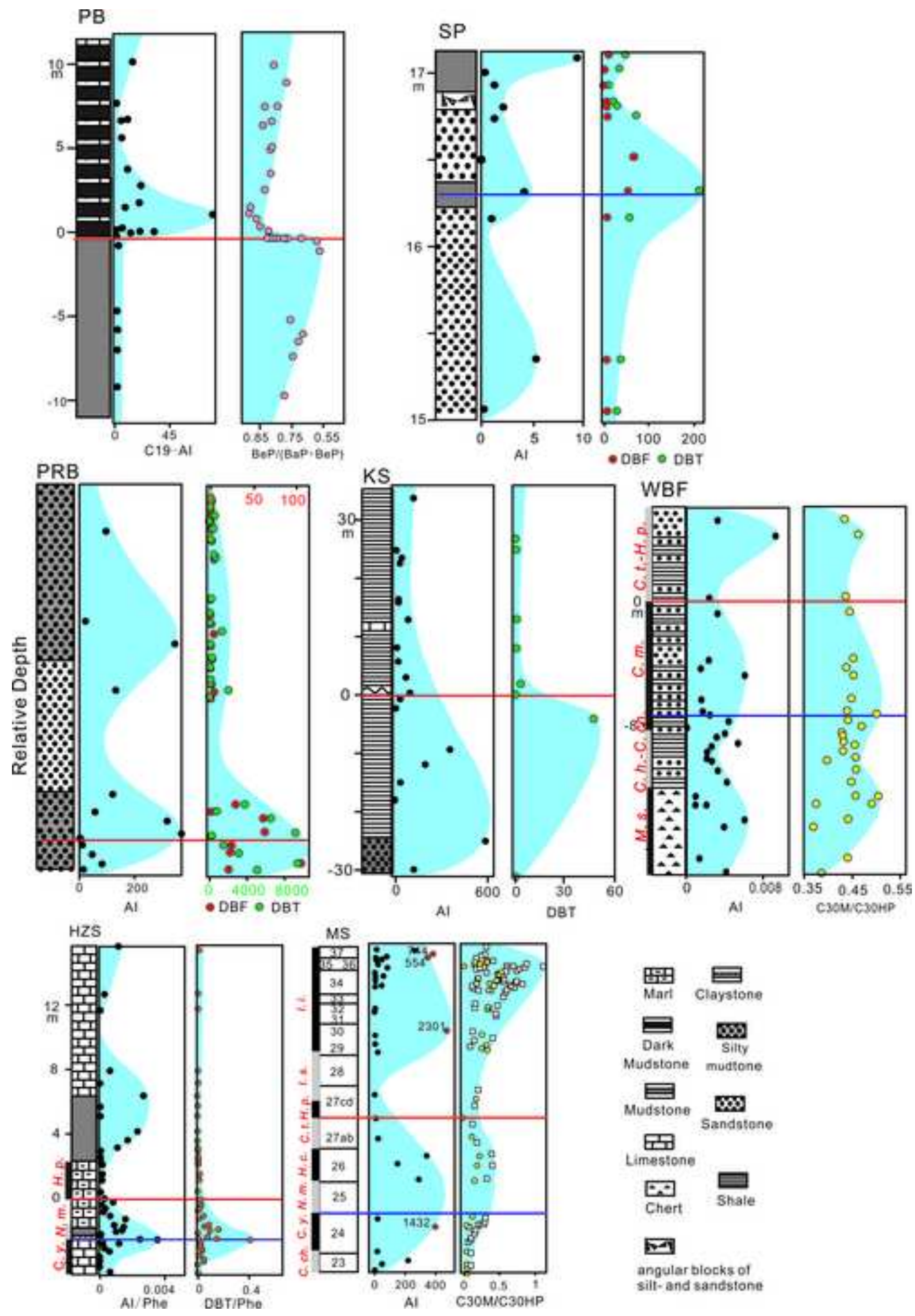

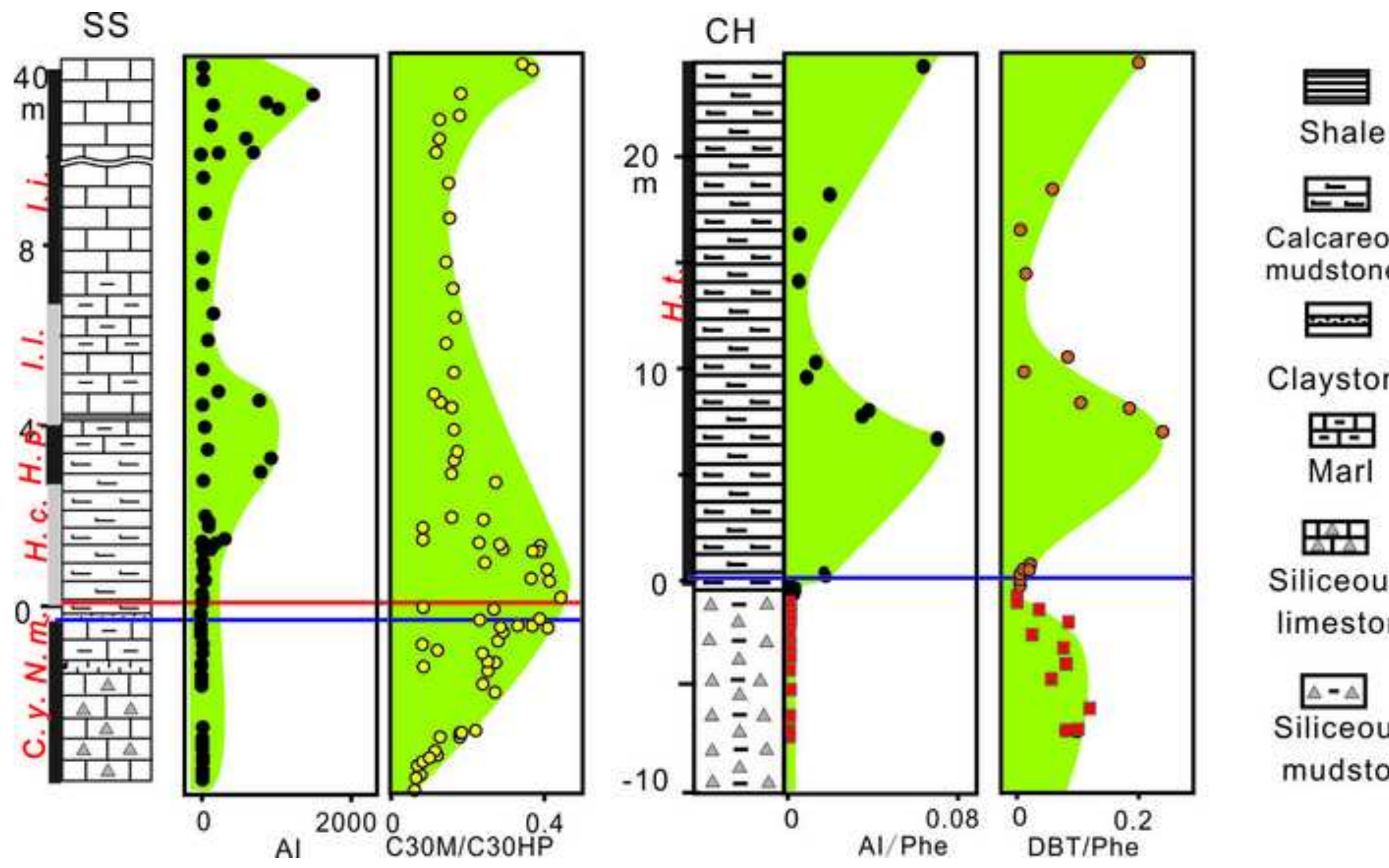

Calcareous mudstone

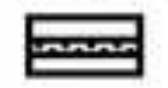

Claystone

묨묘

Marl

\section{स⿴囗十}

Siliceous

limestone

$\Delta-\Delta$

Siliceous

mudstone 

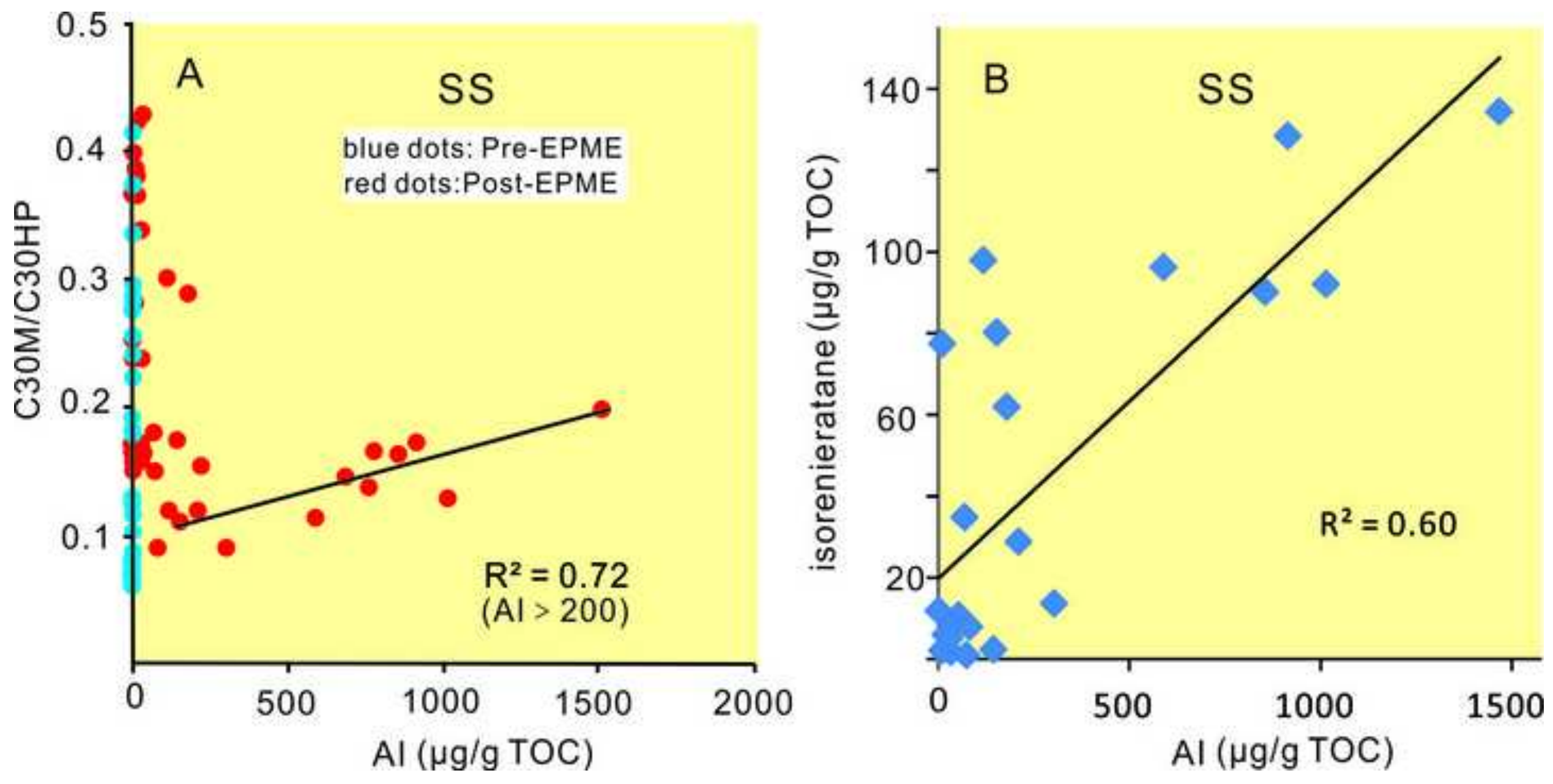

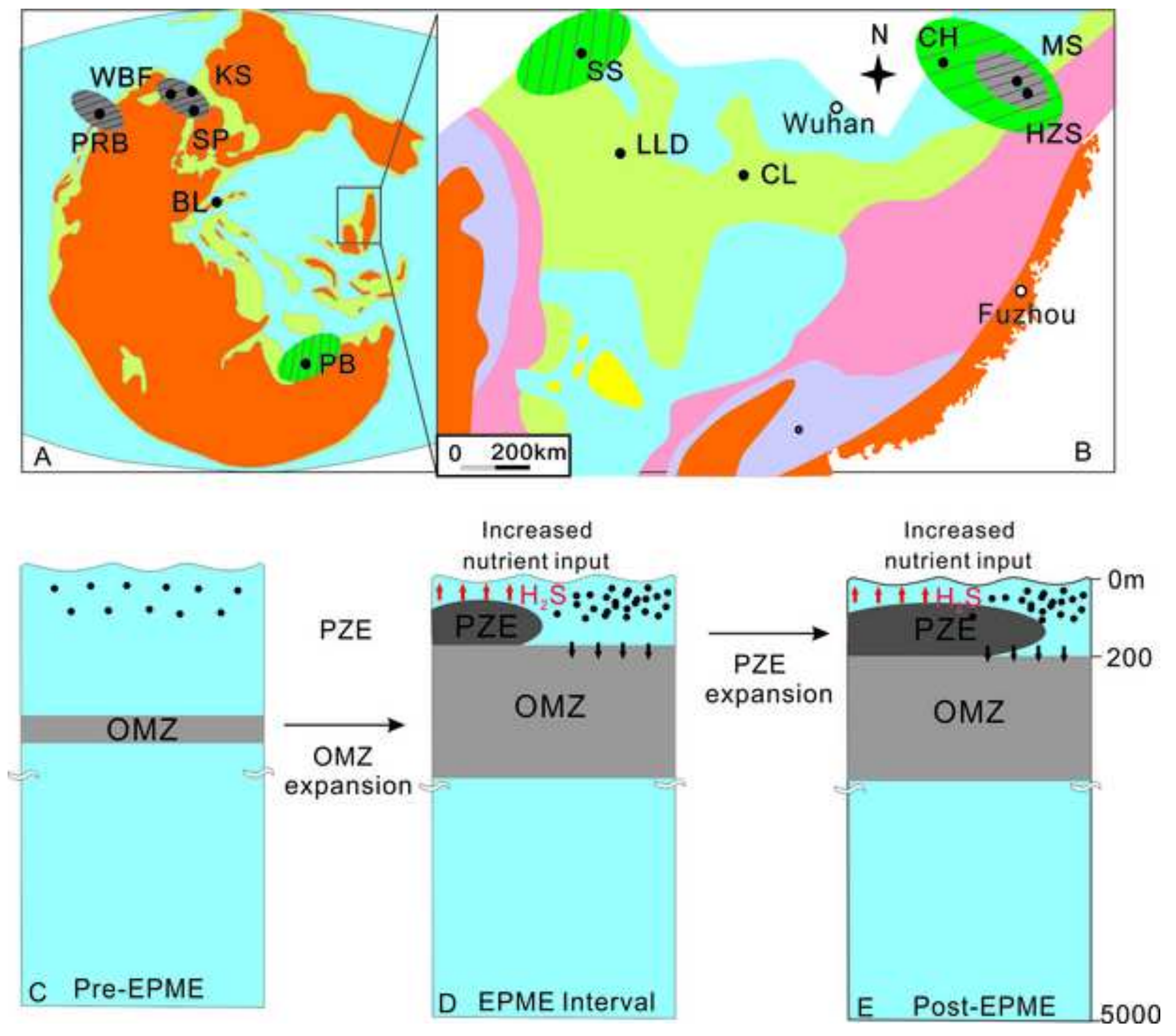


\begin{tabular}{|c|c|c|c|c|c|c|}
\hline Sections & $\begin{array}{l}\text { Paleogeographic } \\
\text { settings }\end{array}$ & $\begin{array}{l}\text { Lithology of the PTB beds } \\
\text { (C. yini-I. isarcia zones) }\end{array}$ & $\begin{array}{l}\text { Water depth } \\
\text { change up section }\end{array}$ & $\begin{array}{l}\text { Environmental } \\
\text { interpretation }\end{array}$ & $\begin{array}{c}\text { Estimated } \\
\text { water depth }\end{array}$ & Principal references \\
\hline $\begin{array}{l}\text { Bulla, northern } \\
\text { Italy }\end{array}$ & western Tethys & $\begin{array}{l}\text { Thick bedded bioclastic limestone to } \\
\text { thin bedded oolitic limestone beds }\end{array}$ & Shallowing & near the FWWB & $\sim 20-30 \mathrm{~m}$ & $\begin{array}{l}\text { Gorjan et al., 2007,2008; } \\
\text { Farabegoli et al., } 2007\end{array}$ \\
\hline Cili, South China & eastern Tethys & $\begin{array}{l}\text { Massive reef like bioclastic limestone to } \\
\text { massive microbialites and oolites }\end{array}$ & Deepening & near the FWWB & $\sim 20-40 \mathrm{~m}$ & $\begin{array}{l}\text { Wang et al., 2009; Luo } \\
\text { et al., } 2013\end{array}$ \\
\hline $\begin{array}{l}\text { Laolongdong, } \\
\text { South China }\end{array}$ & eastern Tethys & $\begin{array}{l}\text { Thick bedded to massive bioclastic } \\
\text { limestone to massive microbialites }\end{array}$ & Deepening & near the FWWB & $\sim 20-40 \mathrm{~m}$ & $\begin{array}{l}\text { Wu et al., 2006; Liu et } \\
\text { al., 2010; Liao et al., } \\
2010\end{array}$ \\
\hline $\begin{array}{l}\text { Huangzhishan, } \\
\text { South China }\end{array}$ & eastern Tethys & $\begin{array}{l}\text { Medium-thick bedded bioclastic } \\
\text { limestone to thin-medium bedded muddy } \\
\text { limestone with claystone and mudstone }\end{array}$ & Deepening & $\begin{array}{l}\text { upper part of } \\
\text { FWWB-SWB zone }\end{array}$ & $\sim 40-80 \mathrm{~m}$ & Chen et al., 2009 \\
\hline $\begin{array}{l}\text { Hovea-1, Perth } \\
\text { Basin, Australia }\end{array}$ & $\begin{array}{l}\text { northern margin of } \\
\text { Gondwana }\end{array}$ & $\begin{array}{l}\text { Mudstone, sandy siltstone and shelly } \\
\text { storm beds to finely laminated mudstone } \\
\text { and thin bedded limestone }\end{array}$ & Deepening & $\begin{array}{l}\text { lower part of } \\
\text { FWWB-SWB }\end{array}$ & $\sim 20-50 \mathrm{~m}$ & Thomas et al., 2004 \\
\hline $\begin{array}{l}\text { Spitsbergen, } \\
\text { Norway }\end{array}$ & $\begin{array}{l}\text { shelf sea in Boreal } \\
\text { Ocean }\end{array}$ & $\begin{array}{l}\text { Sandstone with few mudstone to } \\
\text { mudstone with sandstone, and thin } \\
\text { bedded limestone }\end{array}$ & Deepening & near the SWB & $\sim 60-80 \mathrm{~m}$ & $\begin{array}{c}\text { Mørk et al., 1999; } \\
\text { Nabbefeld et al., } 2010\end{array}$ \\
\hline $\begin{array}{l}\text { Peace River } \\
\text { Basin, Arctic } \\
\text { Canada }\end{array}$ & $\begin{array}{l}\text { northwestern } \\
\text { margins of Pangea }\end{array}$ & Silty mudstone to Sandstone & Shallowing & near the SWB & $\sim 80-100 \mathrm{~m}$ & Hays et al., 2007 \\
\hline Kap Stosch & $\begin{array}{l}\text { margin of Boreal } \\
\text { Ocean (Greenland) }\end{array}$ & Shale and Siltstone to sandstone & Shallowing & near the SWB & $\sim 80-100 \mathrm{~m}$ & Hays et al., 2012 \\
\hline $\begin{array}{l}\text { Meishan, South } \\
\text { China }\end{array}$ & eastern Tethys & $\begin{array}{l}\text { Medium-thick bedded bioclastic } \\
\text { limestone to Thin bedded clay beds; thin } \\
\text { bedded mudstone/shale; } \\
\text { medium bedded limestone }\end{array}$ & Deepening & FWWB-SWB zone & $\sim 80-100 \mathrm{~m}$ & $\begin{array}{l}\text { Zhang et al., 1996; Chen } \\
\text { et al., 2007, 2015; Tian } \\
\text { et al., } 2014\end{array}$ \\
\hline $\begin{array}{l}\text { West Blind } \\
\text { Fjord, Arctic } \\
\text { Canada }\end{array}$ & $\begin{array}{l}\text { Boreal Ocean } \\
\text { basin }\end{array}$ & Chert to sandstone and siltstone & Shallowing & Below the SWB & $\sim 100-200 \mathrm{~m}$ & Algeo et al., 2012 \\
\hline $\begin{array}{l}\text { Shangsi, South } \\
\text { China }\end{array}$ & eastern Tethys & $\begin{array}{c}\text { Thin bedded siliceous limestone to clay } \\
\text { beds and thin bedded carbonaceous } \\
\text { mudstone }\end{array}$ & Shallowing & inner shelf basin & $\sim 200-300 \mathrm{~m}$ & $\begin{array}{l}\text { Wignall et al., 1999; } \\
\text { Song-HJ et al., 2012; } \\
\quad \text { Lei et al., } 2012\end{array}$ \\
\hline
\end{tabular}


Chaohu, South China
Thin bedded siliceous

Mudstone to medium bedded

eastern Tethys arbonaceous limestone and claystone
Shallowing

inner shelf basin 200-400m

Chen al., 2011; Song-HY et al., 2013 